\title{
Glioblastoma stem cells: lessons from the tumor hierarchy in a lethal cancer
}

\author{
Ryan C. Gimple, ${ }^{1,2}$ Shruti Bhargava, ${ }^{1}$ Deobrat Dixit, ${ }^{1}$ and Jeremy N. Rich ${ }^{1,3}$ \\ ${ }^{1}$ Division of Regenerative Medicine, Department of Medicine, University of California at San Diego, La Jolla, California 92037, \\ $\mathrm{USA}_{;}{ }^{2}$ Department of Pathology, Case Western Reserve University, Cleveland, Ohio 44106, USA; ${ }^{3}$ Department of Neurosciences, \\ University of California at San Diego School of Medicine, La Jolla, California 92037, USA
}

Glioblastoma ranks among the most lethal of all human cancers. Glioblastomas display striking cellular heterogeneity, with stem-like glioblastoma stem cells (GSCs) at the apex. Although the original identification of GSCs dates back more than a decade, the purification and characterization of GSCs remains challenging. Despite these challenges, the evidence that GSCs play important roles in tumor growth and response to therapy has grown. Like normal stem cells, GSCs are functionally defined and distinguished from their differentiated tumor progeny at core transcriptional, epigenetic, and metabolic regulatory levels, suggesting that no single therapeutic modality will be universally effective against a heterogenous GSC population. Glioblastomas induce a systemic immunosuppression with mixed responses to oncoimmunologic modalities, suggesting the potential for augmentation of response with a deeper consideration of GSCs. Unfortunately, the GSC literature has been complicated by frequent use of inferior cell lines and a lack of proper functional analyses. Collectively, glioblastoma offers a reliable cancer to study cancer stem cells to better model the human disease and inform improved biologic understanding and design of novel therapeutics.

Tumors are not homogeneous masses of neoplastic cells; rather, they contain ecosystems with diverse neoplastic populations and recruited supportive stroma. Numerous efforts to model the complexity of neoplastic populations have included not only integration of the tumor microenvironment but also efforts to explain heterogeneous tumor cells based on genetic and epigenetic diversity. The cancer stem cell hypothesis represents one element of nongenetic complexity in cancer biology that leverages the similarities between tumorigenesis and both development and wound responses, processes in which normal tissue stem and progenitor cells serve critical roles. The cancer stem cell hypothesis holds that tumors mimic nor-

[Keywords: brain tumor; cancer stem cell; glioblastoma; glioblastoma stem cell; tumor-initiating cell]

Corresponding author: drjeremyrich@gmail.com

Article is online at http://www.genesdev.org/cgi/doi/10.1101/gad.324301. 119. mal tissues with hierarchically arranged and dynamically regulated populations of cells, with stem-like cells at the apex that display regenerative potential and the capacity to recapitulate the entire functional diversity present within the original tumor.

The underpinnings of cancer stem cell modeling date back to early functional studies of cancer, which showed that the injection of a single leukemic cell into mice could produce a lethal leukemia in as little as $2 \mathrm{wk}$ (Furth et al. 1937). In the modern era, the cancer stem cell model was revitalized by Dick and coworkers (Lapidot et al. 1994), who identified a subset of patient-derived leukemia cells able to traffic to the bone marrow of immunodeficient mice, with sustained proliferation and maintenance of the original leukemic cell phenotypes. Leukemia-initiating cells differentiate in vivo and possess self-renewal properties (Bonnet and Dick 1997). These landmark studies kicked off the hunt for cancer stem cells in additional tumor types, including breast cancer (Al-Hajj et al. 2003), brain cancer (Hemmati et al. 2003; Singh et al. 2003, 2004), prostate cancer (Collins et al. 2005), colorectal cancer (O'Brien et al. 2007; Ricci-Vitiani et al. 2007), and pancreatic cancer (Li et al. 2007). Amid the rapid pace of identification of novel cancer stem cells in a variety of cancer types, challenges to the cancer stem cell model have been raised: (1) the relevance of the cancer stem cell model to inform our understanding of the disease state and guide therapeutic development, (2) the cell of origin of cancer stem cells in many tumor types, and (3) the liberal use of the term "cancer stem cell" without strict adherence to the required functional definition.

\section{Clinical relevance of glioblastoma stem cells (GSCs)}

Glioblastoma is the most common of all primary malignant central nervous system (CNS) tumors, with a dismal 5 -yr survival rate of only $5 \%$ and a median survival of $<15$ mo (Stupp et al. 2009; Ostrom et al. 2015).

(C) 2019 Gimple et al. This article is distributed exclusively by Cold Spring Harbor Laboratory Press for the first six months after the full-issue publication date (see http://genesdev.cshlp.org/site/misc/terms.xhtml). After six months, it is available under a Creative Commons License (Attribution-NonCommercial 4.0 International), as described at http://creativecommons.org/licenses/by-nc/4.0/. 
Glioblastomas are classified by the presence of characteristic mutations, which often provide prognostic information, and also into three main tumor-intrinsic transcriptional subtypes: proneural, classical, and mesenchymal, although significant intratumoral heterogeneity exists (Wang et al. 2017a). Current standard of care includes gross total surgical resection followed by concurrent treatment with radiotherapy and temozolomide, a cytotoxic chemotherapy (Stupp et al. 2005, 2009). Tumor-treating fields (TTFs) represent a new therapeutic modality that extends overall patient survival from 16 to 20.9 mo when used in combination with radiotherapy and chemotherapy (Stupp et al. 2017).

Major contributors to the poor prognosis of glioblastoma patients include a high degree of intratumoral cellular heterogeneity and plasticity, the infiltrative and migratory nature of glioblastoma cells, and a high rate of recurrence. Recurrent tumors are frequently evolutionarily divergent from the original tumor, with distinct drivers and sensitivities, limiting the informative capacity of initial biopsies when treating recurrent disease (Kim et al. 2015b). Many of these features can be modeled through the lens of the cancer stem cell hypothesis. Functionally defined GSCs have been identified in human brain tumors (Singh et al. 2003, 2004) and play important roles in mediating therapeutic resistance through supporting radioresistance (Bao et al. 2006a), chemoresistance (Liu et al. 2006; Chen et al. 2012), angiogenesis (Bao et al. 2006b; Cheng et al. 2013), invasion (Wakimoto et al. 2009), and recurrence (Chen et al. 2012). Both in vitro and in vivo observations support the existence of subpopulations of human tumor cells that express stemness-related markers, are capable of initiating tumors, and recapitulate tumor heterogeneity when injected orthotopically into mice (Singh et al. 2004; Lee et al. 2006). Thus, gaining a deeper understanding of the underlying molecular processes that drive cancer stem cell maintenance, plasticity, and resiliency will enhance our ability to selectively target and ablate these tumor-initiating and -propagating populations.

In glioblastoma, cancer stem cell controversies largely stem from a vague and disputed definition of GSCs. Here, we suggest a definition based on a series of practical functional criteria that verify the cellular capacity to selfrenew, initiate tumors upon serial transplantation, and recapitulate tumor cell heterogeneity (Fig. 1A). This definition is inherently retrospective, as cancer stem cells can
A

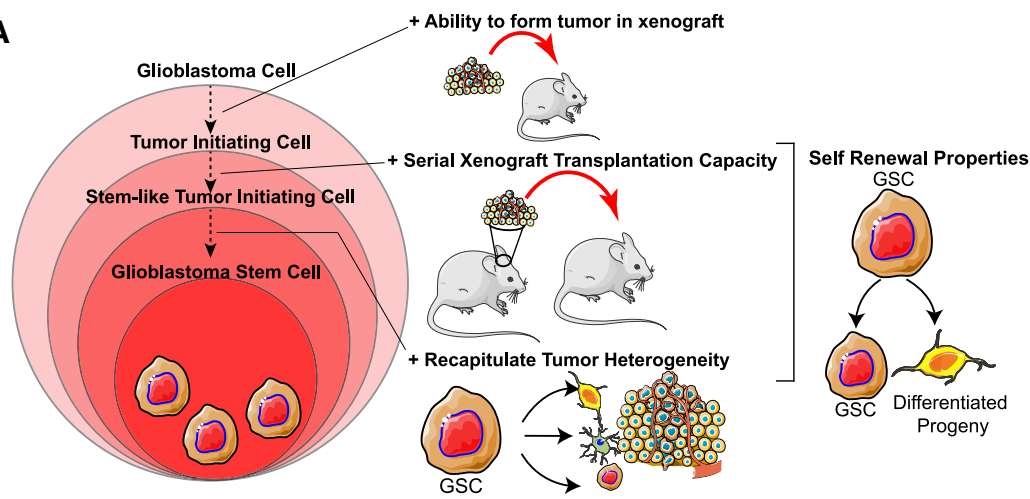

B

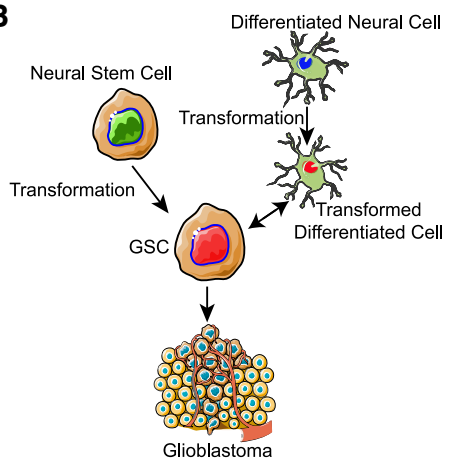

C

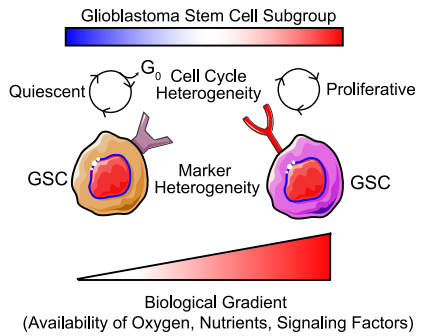

Figure 1. GSC definition and key features. $(A)$ GSCs are defined by a series of functional criteria, including tumor-initiating capacity following serial transplantation, self-renewal, and the ability to recapitulate tumor heterogeneity. (B) GSCs may arise from neural stem cells or transformed astrocytes that gain access to stem-specific transcriptional programs. $(C)$ GSCs display cellular and phenotypic heterogeneity dependent on anatomic location within the tumor and distinct microenvironmental cues. (D) The GSC model allows for hierarchical rigidity and plasticity models.

D

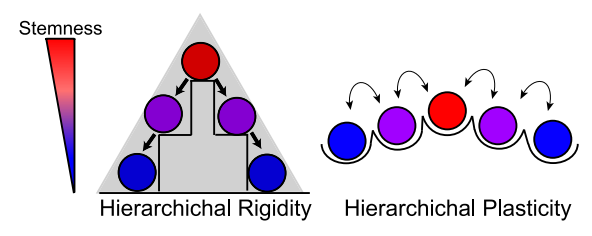


be conclusively identified only after performing an experiment that alters the state of the original cell, precluding a prospective identification of GSCs through the use of cell surface or other cellular markers. While it is important to agree on a functional definition for GSCs to determine their relevance in disease and mechanisms to selectively target these cells, it is equally important to understand the limitations of this model. First, the term "glioblastoma stem cell" does not make any claims about tumor cell of origin. While the presence of GSCs may imply the malignant transformation of a normal tissue stem cell, GSCs may also arise from more differentiated neoplastic cells that gain access to stem-like developmental and survival programs through genetic perturbations (Fig. 1B). Second, GSCs are not defined by the presence or absence of molecular markers. Although certain cellular features (such as CD133, CD44, and CD15) may enrich the frequency of GSCs within cellular populations, these markers are not completely sensitive or specific for GSC populations (Beier et al. 2007). Third, the GSC definition does not suggest that the stem state is static. A striking plasticity exists between different cellular states of the tumor, which allows for interconversion between GSC and non-GSC states depending on a number of factors. Microenvironmental exposures, including nutrient deprivation, hypoxia, radiation, and others, shift the dynamics of regulation of these interconversions, bringing about changes in the GSC and non-GSC pools, along with phenotypes such as proliferation or quiescence (Fig. 1C,D). Fourth, while the GSC model highlights the importance of stem-like cell populations in mediating cellular heterogeneity and disease recurrence, the GSC model does not make claims about the frequency of this cell type within tumors or diminish the role of more differentiated progeny cells that play critical roles in the maintenance of complex tumor tissue systems. Here, we provide a review of the most recent evidence regarding the existence of GSCs in glioblastoma tumors and progress made in defining their key molecular regulators, with an eye toward harnessing these breakthroughs to inform the development of novel therapeutic strategies.

\section{Emerging evidence of cancer stem cells in glioma and glioblastoma}

Recent technological advances, including single-cell RNA sequencing (scRNA-seq) approaches and lineagetracing barcoding methods, have provided further evidence for the existence of a population of GSCs in human glioblastoma tumors. These studies allow for less biased identification of stem-like populations in their native environments without relying on culture, although these analyses are limited by reliance on cellular markers without validation of the required functional characteristics. scRNA-seq of primary tumor specimens captured the great extent of intratumoral heterogeneity and identified a slow-dividing quiescent population of stem-like cells in glioblastoma tumors (Patel et al. 2014). Tumor cells exist in a continuous spectrum along the stemness-differentiation axis and not as discrete populations, as are often stud- ied in vitro (Patel et al. 2014). In oligodendrogliomas, scRNA-seq revealed the presence of undifferentiated stem-like cells with enrichment for cell cycle and proliferative transcriptional programs, suggesting that these stem-like cells support tumor growth (Tirosh et al. 2016). Single-cell sequencing of pediatric gliomas bearing histone Histone 3 Lys27 (H3K27M) mutations revealed four broad expression programs in their constituent cells, including an oligodendrocyte precursor cell (OPC)-like program, with up-regulation of cell cycle genes (Filbin et al. 2018). Undifferentiated stem-like precursor cells were also identified that may serve as a common initiating cell for both isocitrate dehydrogenase 1 (IDH1) mutant astrocytomas and oligodendrogliomas. In this study, stem cell and cell cycle genes were positively correlated at the single-cell level (Venteicher et al. 2017). While normal neural stem cells are commonly quiescent, other normal tissues (e.g., the skin and gastrointestinal systems) contain discrete self-renewing populations that can be highly proliferative or quiescent. Thus, divergent proliferative potentials for GSCs may capture this diversity, although there may also be differences between high- and low-grade gliomas or cancer stem cells that reside at different stages of the stemness gradient with distinct proliferative capacities. Lineage-tracing approaches and mathematical modeling of successive xenograft outgrowth assays using human glioblastoma cells suggest that slow-cycling stem cells undergo limited asymmetric cell division to generate a transit-amplifying progenitor-like population that generates short-lived differentiated progeny (Lan et al. 2017). Together, these granular approaches have advanced our understanding of GSCs in their native environment.

\section{Glioblastoma cell of origin}

Although glioblastoma represents the first and one of the most highly characterized cancers by The Cancer Genome Atlas (TCGA) at the genomic level (Brennan et al. 2013; Ceccarelli et al. 2016), controversy remains with respect to its precise cell of origin. While some contend that glioblastomas arise from a subpopulation of neural stem cells, others argue that transformation of more differentiated astrocytes may give rise to glioblastomas (Fig. 1B). In mouse models, overexpression of active Ras and Akt or inactivation of the p53 and NF1 tumor suppressors in neural progenitor cells, but not in more differentiated astrocytes, was sufficient to induce formation of glioblastoma-like lesions (Holland et al. 2000; Zhu et al. 2005; Alcantara Llaguno et al. 2009). Others show that genetic alterations in either neural stem cells or differentiated astrocytes can give rise to glioblastomas in mouse models (Bachoo et al. 2002).

Reports in the last several years favor neural stem cells, typically localized at the subventricular zone (SVZ) or subgranular zone, as the glioblastoma cell of origin. Immature outer SVZ radial glial cells share a striking transcriptional similarity to glioblastoma cells, suggesting that these cells may be early glioblastoma precursors (Pollen et al. 2015). Overexpression of mutant IDH1, a key driver of low-grade gliomas, in adult SVZ neural stem cells 
induces progenitor cell hyperplasia and tumor-like nodules consistent with early gliomagenesis in a mouse model (Bardella et al. 2016). Deletion of the tumor suppressors NF1, TP53, and PTEN in either neural or oligodendroglial precursor cells induces glioblastoma-like lesions in a mouse model. Disruption of identical tumor suppressor genes in two distinct progenitor cell populations gave rise to distinct diseases, with neural precursor-derived tumors demonstrating more aggressive phenotypes than their oligodendrocyte precursor-derived counterparts (Alcantara Llaguno et al. 2015). PTEN mutations in neural stem cells are also able to induce neoplastic transformation, while the same mutations in mesenchymal stem cells do not (Duan et al. 2015). These data suggest that the unique underlying molecular features of different neural progenitor cell populations poise particular populations for tumorigenesis and endow the resulting tumor with distinct functional properties, highlighting the importance of understanding the cell of origin.

Compelling evidence from a series of high-throughput sequencing and mouse modeling approaches has suggested that astrocyte-like stem cells from the astrocytic ribbon layer of the SVZ are the glioblastoma cell of origin, further substantiating prior reports (Lee et al. 2018). Whole-exome and single-cell sequencing analyses from matched human glioblastoma tissue and normal SVZ tissue revealed that (1) approximately half of patients contained shared mutations between tumor and SVZ tissue, (2) most somatic mutations and copy number alterations were tumor-private, and (3) single-cell clones from SVZ tissue with mutations shared with the tumor tissue lacked tumor-private mutations. Mouse modeling data showed that induction of mutations within the SVZ promoted tumor formation and migration from the SVZ, while the same mutations did not lead to tumor initiation when induced in cortical astrocytes (Lee et al. 2018). These recent reports highlight the importance of cellular background in the establishment of glioblastomas and suggest that neural precursor populations are uniquely situated for malignant transformation following the appropriate genetic insults. Taken together, these studies support a cancer stem cell model in gliomas whereby a small population of GSCs derived from transformed SVZ-derived neural stem cells acts to maintain tumor heterogeneity, although controversy remains regarding the applicability of mouse modeling data to the human disease. In the following sections, we review the field's progress in understanding the defining molecular characteristics and potential targetable vulnerabilities of this stem cell population.

\section{Modeling glioblastoma: isolation, enrichment, and propagation of GSCs}

Strategies to isolate and enrich cancer stem cells are based on the methods used to isolate their normal counterparts: tissue stem cells. These methods involve using specific cellular markers and growing cells in defined suspension cultures to distinguish between GSCs and other nonstem tumor cells. Strategies to identify GSCs using cellular markers rely on the sensitivity and specificity of cell surface factors to enrich for stem-like populations. However, the spectrum of GSC markers has an extensive overlap with those used for identification of neural stem cells. These include intracellular proteins (SOX2, OLIG2, MYC, and NESTIN) and the cell surface markers (CD133, L1CAM, CD44, and A2B5) (Brescia et al. 2012). As we understand the biology of GSCs in greater depth, we should re-evaluate these current methods. The neurosphere formation assay depends on self-renewal properties of GSCs, which allows for growth within defined nonadherent medium conditions. Caveats with this method include the inability to reflect the precise number of cells with in vivo tumor formation capacity and the inability to detect quiescent stem cells. An alternative to neurosphere cultures is two-dimensional adherent culture of GSCs on poly-L-lysine/laminin-coated plates, which reduces cellular differentiation (Lee et al. 2006). However, both of these methods fail to properly model the interaction of GSCs with the various other cell types that exist in vivo.

Recently, three-dimensional GSC organoid culture systems have been developed, which more faithfully recapitulate in vivo tumor growth, cellular heterogeneity, and hypoxic gradients (Hubert et al. 2016). CRISPR-Cas9 genomic editing can also be used to generate glioblastoma organoid models. Introduction of the HRas ${ }^{\mathrm{G} 12 \mathrm{~V}}$ allele into the TP53 locus in cells of cerebral organoids drove invasive phenotypes both in the organoid model and when orthotopically xenografted in immunodeficient mice with transcriptional similarities to mesenchymal tumors (Ogawa et al. 2018). Somatic in vivo CRISPR/Cas9-mediated genomic editing approaches have also been applied to study glioblastomas in mouse models /Oldrini et al. 2018) and have allowed for the performance of large-scale screens in vivo (Chow et al. 2017). These organoid and animal systems may better model in vivo environments to improve our understanding of GSCs in their appropriate physiological context. Despite these advances, new methods for the prospective isolation and propagation of GSCs are required. The ideal in vitro assay should accurately assess the tumor formation ability of GSCs, be largely independent of growth mediated by high amounts of exogenous growth factors, incorporate various cellular interactions, and recapitulate the tumor microenvironment. Furthermore, efforts should be made to develop models that reflect the diverse mutational spectrum of glioblastoma to more completely understand the role of genetic background in cellular dependencies and therapeutic response (Table 1).

\section{Glioma stem cell epigenetics: interface between environment and cellular response}

While nearly every cell in the human body contains an identical genomic blueprint, epigenomic regulation of this genomic code allows for the generation of cell and developmental stage-dependent transcriptional programs through opening relevant genomic regions while sequestering others (Fig. 2A). Appropriate epigenetic regulation is critical for the maintenance of GSCs and serves to 
Table 1. Advantages and limitations of GSC and glioblastoma models

\begin{tabular}{|c|c|c|c|}
\hline $\begin{array}{l}\text { GSC modeling } \\
\text { methods }\end{array}$ & Advantages & Limitations & References \\
\hline $\begin{array}{l}\text { Sorting using cellular } \\
\text { markers (CD133, } \\
\text { CD15, and others) }\end{array}$ & $\begin{array}{l}\text { Prospective identification of } \\
\text { putative stem populations } \\
\text { is possible }\end{array}$ & $\begin{array}{l}\text { Individual stem markers are } \\
\text { frequently disputed; no functional } \\
\text { criteria are used; may deplete GSC } \\
\text { heterogeneity; integrity of surface } \\
\text { markers may be affected during } \\
\text { single-cell dissociation }\end{array}$ & $\begin{array}{l}\text { Galli et al. 2004; Singh et al. 2004; } \\
\text { Bidlingmaier et al. 2008; Gilbert } \\
\text { and Ross 2009; Son et al. 2009; } \\
\text { Wan et al. } 2010\end{array}$ \\
\hline $\begin{array}{l}\text { In vitro neurosphere } \\
\text { culture }\end{array}$ & $\begin{array}{l}\text { Uses a functional assay for } \\
\text { self-renewal capacity; } \\
\text { high throughput }\end{array}$ & $\begin{array}{l}\text { Inability to determine tumor } \\
\text { formation capacity, identify } \\
\text { quiescent stem populations, and } \\
\text { model diverse cellular interactions; } \\
\text { reliance on artificial and } \\
\text { unphysiological medium conditions } \\
\text { with loss of tumor heterogeneity; } \\
\text { contain populations of stem and } \\
\text { differentiated cells; not ideal for } \\
\text { assays in which homogeneity is } \\
\text { required; percentage of enriched } \\
\text { GSCs will vary with every sphere } \\
\text { depending on size, passage, and } \\
\text { technique used in propagation and } \\
\text { culture medium }\end{array}$ & $\begin{array}{l}\text { Lee et al. 2006; Wan et al. 2010; } \\
\text { Pastrana et al. } 2011\end{array}$ \\
\hline $\begin{array}{l}\text { Two-dimensional } \\
\text { adherent culture on } \\
\text { poly-L-lysine/ } \\
\text { laminin plates }\end{array}$ & $\begin{array}{l}\text { May reduce differentiation } \\
\text { compared with } \\
\text { neurosphere culture; ideal } \\
\text { for assays in which } \\
\text { homogeneity is required; } \\
\text { high throughput }\end{array}$ & $\begin{array}{l}\text { Inability to determine tumor } \\
\text { formation capacity, identify } \\
\text { quiescent stem populations, and } \\
\text { model diverse cellular interactions; } \\
\text { reliance on artificial and } \\
\text { unphysiological medium conditions } \\
\text { with loss of tumor heterogeneity }\end{array}$ & Pollard et al. 2009 \\
\hline $\begin{array}{l}\text { Three-dimensional } \\
\text { GSC organoid } \\
\text { culture systems and } \\
\text { biomaterial scaffolds }\end{array}$ & $\begin{array}{l}\text { Recapitulate in vivo } \\
\text { environment with higher } \\
\text { fidelity than in vitro } \\
\text { systems; model cellular } \\
\text { and stromal interactions; } \\
\text { model hypoxic and other } \\
\text { biologic gradients; model } \\
\text { multicellular and } \\
\text { microenvironmental } \\
\text { interactions }\end{array}$ & $\begin{array}{l}\text { Decreased throughput compared with } \\
\text { two-dimensional methods; complex } \\
\text { procedure for initiation and } \\
\text { maintenance; lack certain cellular } \\
\text { interactions, including with } \\
\text { vasculature, microglia, and others }\end{array}$ & $\begin{array}{l}\text { Hubert et al. 2016; Bian et al. 2018; } \\
\text { Ogawa et al. 2018; Langer et al. } \\
2019\end{array}$ \\
\hline $\begin{array}{l}\text { Genetically engineered } \\
\text { and syngeneic mouse } \\
\text { modeling approaches }\end{array}$ & $\begin{array}{l}\text { Allow for studies of tumor } \\
\text { initiation and progression } \\
\text { with ability to model } \\
\text { cellular and immune } \\
\text { interactions in a native in } \\
\text { vivo environment }\end{array}$ & $\begin{array}{l}\text { Systems to generate murine tumors } \\
\text { do not fully recapitulate } \\
\text { tumorigenesis in humans; mouse } \\
\text { tumors may be fundamentally } \\
\text { different from the human disease; } \\
\text { expensive and labor-intensive }\end{array}$ & $\begin{array}{l}\text { Holland et al. 2000; Zhu et al. } \\
\text { 2005; Bardella et al. 2016; Miyai } \\
\text { et al. 2017; Oldrini et al. 2018; } \\
\text { Hambardzumyan et al. } 2009\end{array}$ \\
\hline $\begin{array}{l}\text { Patient-derived } \\
\text { xenograft methods }\end{array}$ & $\begin{array}{l}\text { Allow for studies of human } \\
\text { cancers with an ability to } \\
\text { model cellular } \\
\text { interactions in a more } \\
\text { physiologic in vivo } \\
\text { environment }\end{array}$ & $\begin{array}{l}\text { Require immediate generation } \\
\text { following tumor surgical resection; } \\
\text { inability to assess mechanisms of } \\
\text { tumor initiation or model adaptive } \\
\text { immune interactions; serial } \\
\text { passaging may deplete } \\
\text { heterogeneity and induce genomic } \\
\text { alterations; expensive and labor- } \\
\text { intensive }\end{array}$ & $\begin{array}{l}\text { Singh et al. 2004; Hidalgo et al. } \\
\text { 2014; Ben-David et al. 2017; Jung } \\
\text { et al. } 2018\end{array}$ \\
\hline
\end{tabular}

integrate information from numerous cellular inputs. The presumed initiating event in low-grade gliomas (along with other cancers) is mutation of IDH1 or IDH2, which generates widespread epigenomic dysregulation through generation of the glioma-CpG island methylator phenotype (G-CIMP) hypermethylator phenotype (Turcan et al.
2012). The epigenetic alterations induced by IDH mutation in vitro are partially reversible, contribute to transcriptional remodeling and deposition of histone modifications at specific genomic loci, promote the emergence of a CD24 $4^{+}$ stem-like population, and contribute to increased genomic instability (Turcan et al. 2018). In addition to the more 


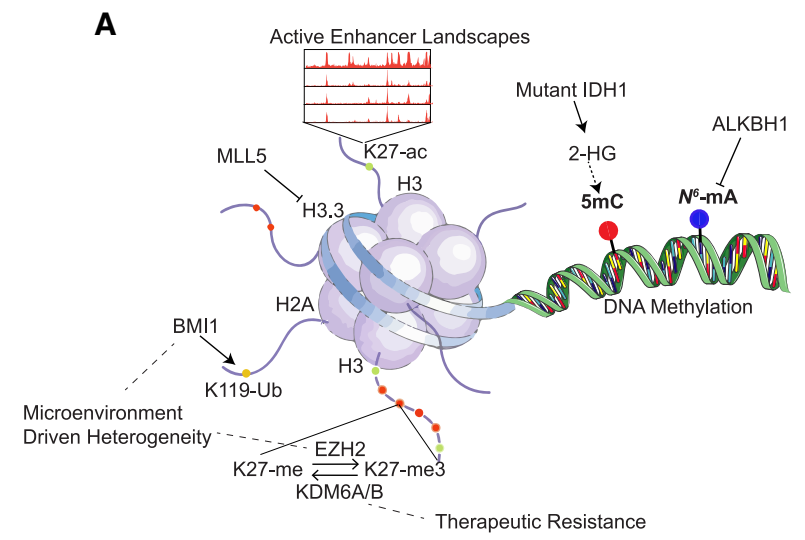

B

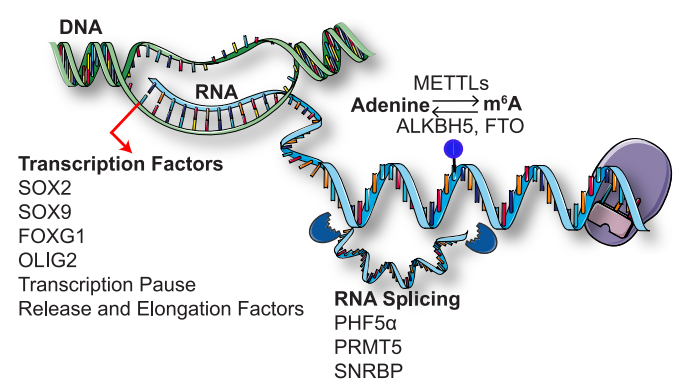

Figure 2. Epigenetic and posttranscriptional regulation of GSCs. (A) Critical epigenetic regulators drive GSC maintenance and response to external cues by regulating gene expression programs. (2-HG) (R)-2-hydroxyglutarate; $\left(N^{6}-\mathrm{mA}\right) \quad N^{6}$-methyladenine; (5mC) 5-methylcytosine; (K27-ac) acetylation of histone 3 on Lys27; (K27-me) methylation of histone 3 on Lys27; (K119-ub) ubiquitination of histone 2A on Lys119. (B) Transcriptional regulators and posttranscriptional processes modify gene expression to support GSCs. $\left(\mathrm{m}^{6} \mathrm{~A}\right) N^{6}$-methyladenosine.

well-known inhibition of histone and DNA demethylases, the mutant IDH oncometabolite 2-hydroxyglutarate (2HG) establishes a synthetic dependency on glutaminase through inhibiting branched-chain amino acid metabolism (McBrayer et al. 2018). In IDH wild-type glioblastomas, global methylation profiling through reduced representation bisulfite sequencing (RRBS) from primary surgical specimens infers glioblastoma transcriptional subtypes, documents intratumoral heterogeneity of tumor cells as well as immune infiltrates, and detects subtype changes between primary and recurrent tumors (Klughammer et al. 2018). Besides the canonical DNA methylation modification that occurs on the fifth position of cytosine bases (5-methylcytosine [5mc]), noncanonical DNA methylation events occur on the sixth position of adenine bases $\left(N^{6}\right.$-methyladenine $\left.\left[N^{6}-\mathrm{mA}\right]\right)$ regulation of which by the DNA demethylase ALKBH1 plays an important role in GSC maintenance (Xie et al. 2018).

In addition to DNA methylation, profiling of active enhancer landscapes through histone 3 Lys27 acetyl (H3K27ac) chromatin immunoprecipitation (ChIP) followed by deep sequencing (ChIP-seq) to identify tumor subgroup-specific superenhancers classifies tumors and identifies therapeutic targets in brain tumor models, including in ependymoma (Mack et al. 2018) and diffuse intrinsic pontine glioma (DIPG) (Nagaraja et al. 2017). These approaches have informed targeting of FGFR1 and WEE1 in ependymoma and potassium channels and ephrin signaling in DIPG as well as elucidated the potential cell of origin for each of these relatively uncharacterized tumor types.

Individual epigenetic and chromatin remodeling factors drive glioblastoma biology in a context-dependent manner, highlighting the microenvironment-dependent essentiality for epigenetic regulators. Under more physiologic conditions in vivo, transcription pause-release and elongation factors are required for GSC maintenance and survival, while, in cell culture conditions, these factors are dispensable (Miller et al. 2017). Regulators of transcription elongation machinery, including RBPJ, are essential for GSC maintenance and tumor formation capacity (Xie et al. 2016). Even in vivo, drastic intratumoral heterogeneity exists, requiring tumor cells to adapt to their unique environments. In vascular tumor regions defined by a relative abundance of oxygen and nutrients, the PRC2 family epigenetic regulator EZH2 predominates and drives a proneural-like transcriptional profile, while, in nutrient-poor necrotic regions, BMIl signaling is active to drive a mesenchymal-like transcriptional profile and promote survival in a hostile microenvironment (Jin et al. 2017). In addition to intrinsic microenvironmental insults faced by cancer cells, GSCs also adapt to cytotoxic and targeted therapeutic agents to mediate therapy resistance. In response to inhibition of receptor tyrosine kinase signaling, KDM6A/ B-mediated epigenetic remodeling promotes treatment resistance by driving a transition from a rapid proliferative state to a slowed, Notch-dependent quiescent state (Liau et al. 2017). KDM2B also acts as an essential epigenetic remodeler in GSCs, inhibition of which sensitizes cells to lomustine therapy (Staberg et al. 2018).

Epigenetic regulation can act as a gatekeeper to cellular access to stem and differentiation programs. The pioneer transcription factor ASCL1, which serves as a master regulator of neuronal lineage differentiation, can also act to preserve differentiation capacity in GSCs, specifically when cells are treated with Notch inhibitors (Park et al. 2017). Integrative epigenomic analyses revealed that GSCs fail to appropriately remodel their DNA methylation profile in response to differentiation cues, suggesting that epigenetic remodeling factors can lock GSCs into a more primitive state (Zhou et al. 2018).

Canonical drivers of glioblastoma, whether they act as oncogenes or tumor suppressors, can function to shape the GSC epigenome. Constitutive activation of EGFR through the exon 2-7 truncation mutation (EGFRvIII) promotes remodeling of the epigenome through overexpression of the SOX9 and FOXG1 transcription factors, which drive oncogenic and proliferative programs (Liu et al. 2015). FOXG1 and another SOX family member, SOX2, were further implicated in repressing differentiation and supporting stem-like proliferative phenotypes in part through activation of stem regulators and repression of FOXO3 (Bulstrode et al. 2017). A panel of transcription 
factors, including SOX2, OLIG2, and ZEB1, transforms astrocytes into tumor-initiating cells even in the absence of oncogenic driver mutations, suggesting that altered epigenetic landscapes can drive tumor formation (Singh et al. 2017). Another significantly mutated gene in glioblastoma, PTEN, shapes the glioblastoma epigenome through nonenzymatic interactions with the chromatin regulator DAXX, which regulates histone $\mathrm{H} 3.3$ genomic localization (Benitez et al. 2017). Histone H3.3 levels can also be controlled by the chromatin regulatory element MLL5, which is critical for the maintenance of genomic architecture required for persistence in a stem cell state /Gallo et al. 2015).

\section{Posttranscriptional regulation: RNAs as drivers of GSC biology}

In the previous section, we discussed how GSCs fine-tune their genetic and epigenetic programs to regulate gene expression. Another complex node of gene regulation exists at the posttranscriptional level, including regulation of RNA maturation, cellular localization, stability, and alternative splicing of transcripts. These mechanisms contribute to the effective translation of transcripts into functional proteins, which ultimately carry out most cellular functions (Fig. 2B). Many of these processes are regulated by RNA-binding proteins (RBPs), a class of deeply conserved and highly abundant proteins, which form ribonucleoprotein complexes with transcripts to facilitate their functions (Hentze et al. 2018). In glioblastoma, many RBPs are expressed at high levels in patient tumors and portend poor prognosis, including SNRBP, a splicing factor that regulates RNA processing and DNA repair pathways (Correa et al. 2016). RNAi screens of patientderived GSCs identified the splicing factor PHF5a as a selective dependency in GSCs but not in nontransformed controls, such as fibroblasts, astrocytes, and neural stem cells (Hubert et al. 2013). MYC overexpression in GSCs is associated with increased sensitivity to splicing inhibition (Hubert et al. 2013). Splicing factors can also be provided in the form of vesicular secretions from apoptotic cells that promote proliferation and therapy resistance in neighboring cells within a tumor (Pavlyukov et al. 2018). Glioma cells also rely on fine regulation of splicing factors, coordinated by PRMT5, which is essential for preventing inclusion of "detained introns" into transcripts, allowing for their efficient translation (Braun et al. 2017).

In eukaryotes, posttranscriptional messenger RNA (mRNA) modification is an emerging gene regulatory mechanism. Among five reported internal mRNA modifications, methylation at the $N^{6}$ position of adenosine $\left(N^{6}\right.$ methyladenosine $\left.\left[\mathrm{m}^{6} \mathrm{~A}\right]\right)$ is the most abundant and tags $>10,000$ mRNAs in mammalian cells (Dominissini et al. 2012). Although discovered in the early 1970s, the biological significance of $\mathrm{m}^{6} \mathrm{~A}$ mRNA modification has been appreciated only recently due to advances in techniques to locate $\mathrm{m}^{6} \mathrm{~A}$ in the transcriptome and the discovery of $\mathrm{m}^{6} \mathrm{~A}$-specific methylases and demethylases. Although many RBPs have been implicated in cancer development, the functional importance of $\mathrm{m}^{6} \mathrm{~A}$ modifiers in cancer ini- tiation and progression is not well studied. Recently, the $\mathrm{m}^{6} \mathrm{~A}$ demethylase ALKBH5 has been reported to play oncogenic roles in GSCs through supporting proproliferative FOXM1 signaling (Zhang et al. 2017). Similar oncogenic functions of another $\mathrm{m}^{6} \mathrm{~A}$ demethylase, FTO, have been reported in acute myeloid leukemias (Li et al. 2017b). Targeting of this demethylase with molecular inhibitors prolonged survival in orthotopic xenograft models (Cui et al. 2017). In contrast to these findings, both oncogenic and tumor-suppressive roles for $\mathrm{m}^{6} \mathrm{~A}$ methyltransferases METTL3 and METTL14 have been reported in GSCs (Cui et al. 2017; Visvanathan et al. 2018). These reports point toward a complex regulation of the $\mathrm{m}^{6} \mathrm{~A}$ pathway in GSCs and warrant its further in-depth study as a potential target for antiglioblastoma therapy. Last, our knowledge of other types of mRNA modification is expanding, and the role of these activities in cancer remains unexplored. Thus, although we are only beginning to understand the relationship of mRNA modification and cancer, further studies will lead to novel cancer therapeutics to target the epitranscriptome.

Noncoding RNAs, including long noncoding RNAs (lncRNAs) and microRNAs, add another layer of complexity to posttranscriptional gene regulation. lncRNAs determine gene expression by regulating the locus-specific recruitment of chromatin modifiers. The NEAT1 lncRNA supports $\beta$-catenin signaling by regulating EZH2 recruitment in EGFR-driven glioblastomas (Chen et al. 2018). The MALAT1 lncRNA maintains expression of the stemness-associated transcription factor SOX2 by down-regulating miR-129 expression in glioblastoma (Xiong et al. 2018). Over 2500 microRNAs exist in humans, forming complex regulatory networks in which a single microRNA regulates several genes, while each mRNA can be regulated by multiple microRNAs. Malignancy and stemnessassociated microRNAs have been identified in glioblastoma and may regulate genes associated with cancer development and radioresistance (Piwecka et al. 2015). Many of these differentially expressed microRNAs are associated with poor prognosis of glioma patients (Sana et al. 2018). Serum microRNA levels are proposed to serve as noninvasive prognostic predictors in glioblastoma (Zhao et al. 2017). Glioma-associated mesenchymal stem cells release exosomes containing microRNAs to support glioma aggressiveness (Figueroa et al. 2017). Several other studies have documented the therapeutic benefits of microRNAs in preclinical studies (Huse and Holland 2009; Kouri et al. 2015). Targeting the let-7a microRNA with an antimir demonstrated efficacy in mouse xenograft studies through derepressing the let-7a target gene HMGA2 (Halle et al. 2016). mir-10b is overexpressed in glioblastoma, is associated with higher tumor grade and invasive properties, and can be inhibited with antisense oligonucleotides that are efficient in slowing tumor growth in vitro and in vivo (Sun et al. 2011; Teplyuk et al. 2016). MicroRNA-based strategies have the potential to be used in combination with conventional therapies as sensitizing agents (Anthiya et al. 2018). Further deeper screening of novel microRNAs is required for the identification of appropriate microRNA targets for glioblastoma. 


\section{GSC metabolism: fueling tumor growth}

The metabolic dysregulation of cancer cells has been well documented for centuries and has served as an integral component of our understanding of cancer initiation, growth, and adaptation (Hanahan and Weinberg 2011; Pavlova and Thompson 2016). Similar to other types of cancer cells, GSCs have high metabolic demands, some of which support rapid proliferation, and others that drive the maintenance of stemness (Fig. 3). Multiple reports have investigated metabolic networks underlying the bioenergetic capacity of GSCs, which up-regulate high-affinity nutrient transporters, including GLUT3, in part through aberrant integrin signaling networks to obtain sufficient glucose to support rapid metabolism and downstream pathways (Flavahan et al. 2013; Cosset et al. 2017). Glucose obtained in this manner supplies substrates for nucleotide biosynthesis to support GSC proliferation (Wang et al. 2017c). In addition to glucose, GSCs acquire nutrients from other sources, including glutamine and acetate, which provide bioenergetic and proliferative substrates. Glutamine is not used as an anapleurotic substrate to replenish tricarboxylic acid (TCA) cycle intermediates but is instead synthesized de novo in GSCs or taken up from surrounding tumor cells and astrocytes to support purine biosynthesis (Tardito et al. 2015). Both glucose and acetate, but not glutamine, are robustly oxidized in the TCA cycle to support energetic needs in glioblastomas and other brain tumors (Mashimo et al. 2014). Glioblastomas rely on acetylCoA synthetase enzymes (namely, ACSS2) to convert acetate to acetyl-CoA and to allow for oxidation of acetate in the TCA cycle (Mashimo et al. 2014). ACSS2 also has a nuclear role in epigenetic remodeling through repurposing acetate derived from protein deacetylation reactions to support histone acetylation at lysosomal and autoph-

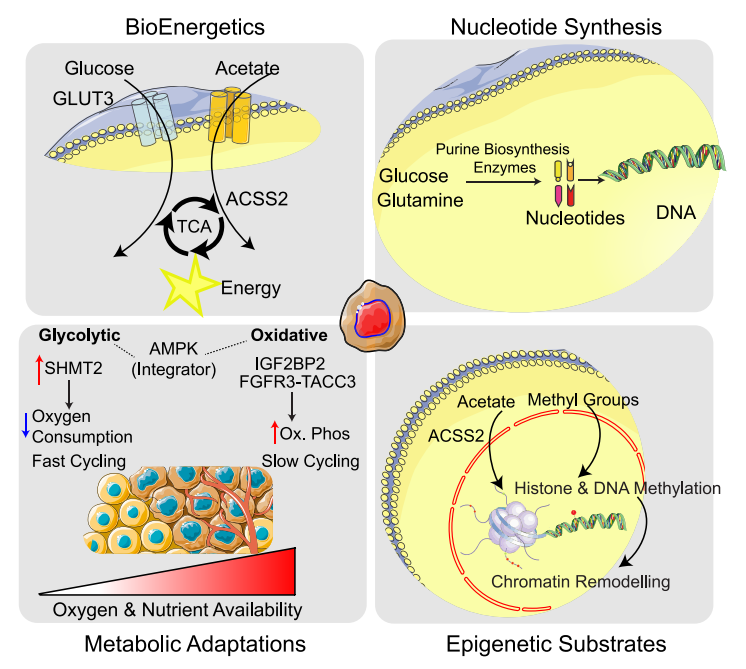

Figure 3. Multiple metabolic pathways power GSCs. GSCs depend on key enzymes to support their bioenergetic needs, requirements for proliferative and epigenetic substrates, and capacity to adapt to harsh microenvironments. (Ox. Phos) Oxidative phosphorylation; (TCA) tricarboxylic acid cycle. agy genes during instances of nutrient deprivation $(\mathrm{Li}$ et al. 2017a). In other cancer models beyond glioma, the intersecting epigenetic and metabolic roles for ACSS2 have been well documented. ACSS2 promotes lipid biosynthesis through mediating histone acetylation under hypoxia or nutrient deprivation conditions (Gao et al. 2016). Other metabolic enzymes, including the nicotinamide regulator NNMT (nicotinamide N-methyltransferase), also play epigenetic roles through regulating cellular methyl donor pools and act to control both histone and DNA methylation as well as protein methylation capacity (Ulanovskaya et al. 2013; Jung et al. 2017; Palanichamy et al. 2017).

GSCs must undergo frequent metabolic adaptations to survive in hostile conditions within rapidly proliferating tumors, which are characterized by low oxygen and nutrients and an abundance of wastes and necrotic tissue. Glioblastoma cells within poorly vascularized necrotic tumor regions up-regulate expression of SHMT2, a serine metabolism enzyme that can limit oxygen consumption by shifting cellular metabolism away from the TCA cycle through inhibition of pyruvate kinase (Kim et al. 2015a). GSCs must scavenge iron from a nutrient-poor microenvironment and selectively up-regulate iron transporters to obtain this critical cofactor (Schonberg et al. 2015). AMP-kinase (AMPK) is important for responding to oncogene-induced and metabolic stressors by regulating glycolysis and mitochondrial metabolism to support energetic requirements (Chhipa et al. 2018). Oxidative metabolism is critical for GSC survival and is regulated through IGF2BP2, which enhances assembly of mitochondrial respiratory chain components and delivery of nuclear-encoded transcripts to the mitochondrial translation machinery (Janiszewska et al. 2012). The FGFR3-TACC3 genetic fusion event in glioblastoma and other tumors drives mitochondrial oxidative phosphorylation to promote tumor growth (Frattini et al. 2018). Dependency on oxidative or nonoxidative metabolism is heterogeneous throughout the tumor, with fast-cycling cells more dependent on anaerobic glycolysis, while slow-cycling cells rely on oxidative phosphorylation and lipid oxidation (HoangMinh et al. 2018).

Similarly to oxidative metabolism, the importance of lipid metabolism has often been overlooked in GSC biology. Fatty acid synthesis enzymes as well as fatty acidbinding proteins have essential roles in maintaining GSCs (De Rosa et al. 2012; Yasumoto et al. 2016). Due to their location behind the neurovascular unit (also called the blood-brain or blood-tumor barrier), GSCs are sequestered from peripheral nutrient pools and thus are dependent on cholesterol metabolism and uptake for survival. These pathways can be selectively targeted using LXR agonists, which disrupt cholesterol uptake, or statins, which impair mevalonate and cholesterol synthesis (Villa et al. 2016; Wang et al. 2017b). EGFR-driven glioblastomas are particularly dependent on lipid metabolism and fatty acid synthesis for survival (Guo et al. 2009) and up-regulate these pathways through activating SREBP-1, a master regulator of lipogenesis, through glycosylation of SCAP (Cheng et al. 2015). Despite the 
findings discussed here, the roles of key metabolic enzymes and the utilization of their respective substrates are certain to be context-dependent. Caution should be used when interpreting results of metabolic profiling studies that are conducted in artificial cell culture systems replete with serum and under high-oxygen conditions.

\section{GSC microenvironment: essential niche factors}

In the previous sections, we described cell-intrinsic programs that GSCs use to adapt to widely variable microenvironmental pressures. Here, we focus on key stromal signaling nodes, including those with vasculature, neurons, different tumor components, and the immune system, and explore how these interactions support GSCs (Fig. 4). At the earliest phases of tumor initiation, cancer cells coopt local vasculature dependent on vessel-derived angiopoietins and tumor-derived vascular endothelial growth factor (VEGF) (Holash et al. 1999; Bao et al. 2006b). While VEGF supports angiogenesis, its inhibition can drive acquisition of invasive mesenchymal phenotypes in certain glioblastoma patients, highlighting its complex role in the tumor ecosystem (Lu et al. 2012). To promote access to nutrients and a path for cell migration, glioma cells home to and invade along blood vessels using an Olig2-Wnt7 signaling axis (Griveau et al. 2018). In mouse models, aberrant oncogene-driven expression of tumor-localized ephrin-B2 ligands subverted normal repulsive interactions with ephrin-B2 on vascular endothelial cells to drive cancer cell invasion and proliferation (Krusche et al. 2016). Osteopontin derived from the perivascular niche serves an oncogenic role by promoting glioma cell survival and aggressiveness through a CD44-HIF2 $\alpha$ axis-dependent activation of hypoxia response genes and maintenance of stem-like properties (Pietras et al. 2014). GSCs also respond to hypoxic environments by up-regulating vasorin, which physically interacts with Notch and promotes its downstream signaling to support GSC maintenance (Man et al. 2018). Hypoxia signaling pathways are aberrantly activated in a GSC-intrinsic manner through the prevention of HIF $2 a$ degradation by high expression of ID2 (Lee et al. 2016).

In addition to receiving growth and survival signals from the vasculature, GSCs remodel vessels by differentiating into vascular pericytes or endothelial-like cells. GSC-

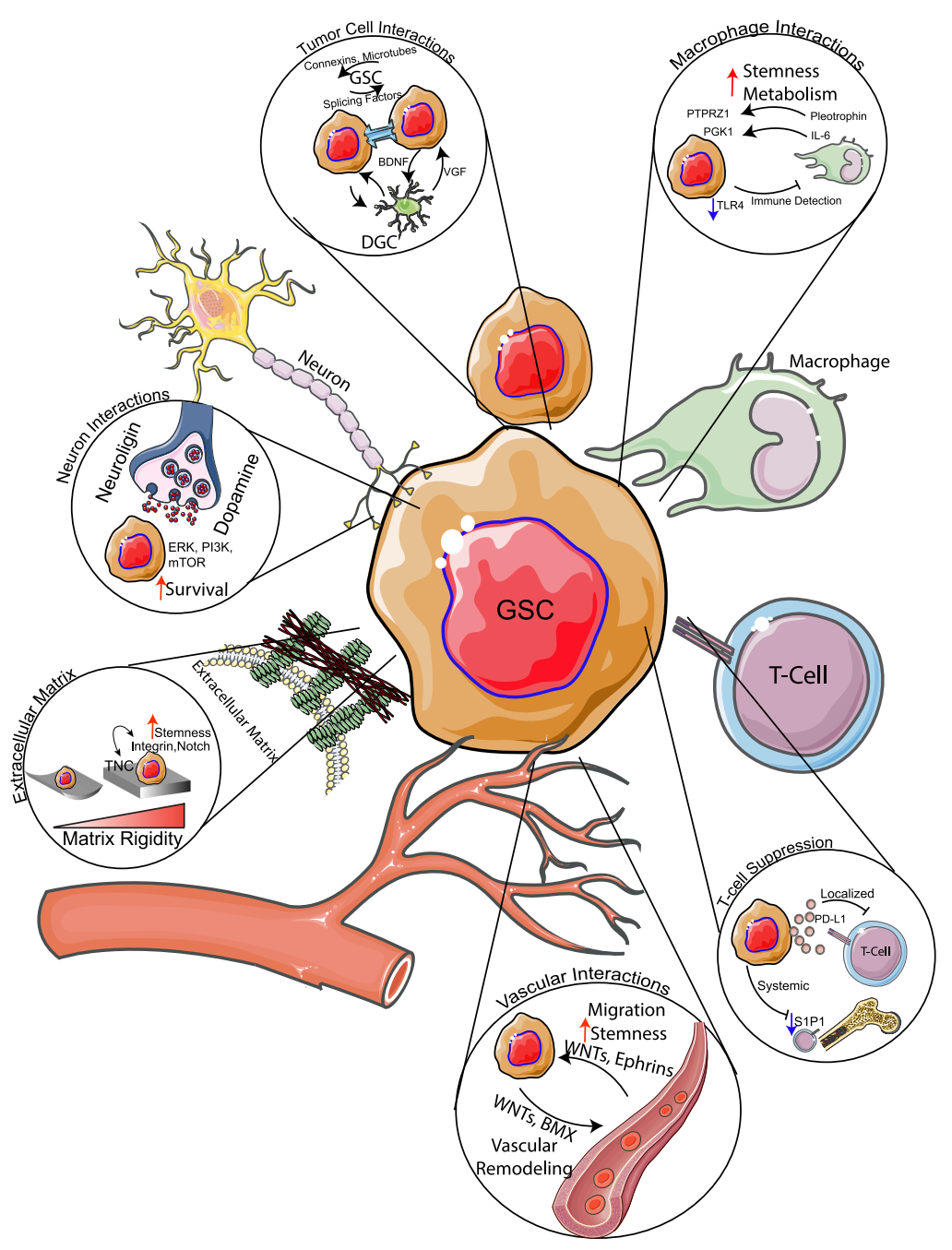

Figure 4. GSCs in context. Microenvironmental interactions with other tumor cells, neurons, macrophages, $\mathrm{T}$ cells, and the vasculature are key for supporting GSCs. 
derived pericytes depend primarily on TGF- $\beta$ and BMX-tyrosine kinase activity to shape their microenvironment and maintain the integrity of the blood-tumor barrier-interactions that can be targeted for therapeutic benefit (Cheng et al. 2013; Zhou et al. 2017; Shi et al. 2018). GSC-derived endothelial-like cells rely on WNT5A signaling to promote cellular lineage infidelity and acquisition of endothelial-like phenotypes, which promotes tumor neovascularization and invasion (Hu et al. 2016).

Signals derived from neuronal components of the tumor microenvironment are similarly critical for maintaining GSCs. Using optogenetic control of neuronal activity in xenograft models, neuronal stimulation was found to promote glioma growth via the soluble mitogen neuroligin-3, which is liberated from neurons (as well as OPCs) by ADAM10 sheddases and functions to support FAK and PI3K-mTOR signaling (Venkatesh et al. 2015, 2017). Dopamine signaling, which presumably originates from neurons, maintains GSCs, as inhibition of the dopamine receptor DRD4 inhibits GSC growth and stem properties through disrupting autophagy and ERK-mTOR signaling pathways (Dolma et al. 2016). Neural precursor cells in the SVZ provide chemoattractant and proinvasive signals to DIPG cells through secretion of pleiotrophin, which maintains RhoA and ROCK signaling (Qin et al. 2017). Jagged, a NOTCH ligand expressed along axons, supports GSC invasion along unmyelinated white matter tracts through up-regulating SOX9 and SOX2 in GSCs (Wang et al. 2019). Furthermore, GSCs adapt to conditions outside of their typical environmental niche. Deletion of the RBP Qki promotes stemness by down-regulating endolysosome-mediated receptor degradation, allowing for limited signaling factors to stimulate stem signaling pathways, including Wnt and Notch signaling (Shingu et al. 2017).

Interactions between tumor and stromal components are also important for maintaining GSCs. In IDH mutant gliomas, high expression of the extracellular matrix glycoprotein tenascin C (TNC) supports increased extracellular matrix stiffness, which increases mechanosignaling through the oncogenic FAK pathway (Miroshnikova et al. 2016). In glioblastoma, TNC supports the maintenance of stemness through activating Notch signaling through binding to cell surface integrins (Sarkar et al. 2017). Extracellular matrix stiffness driven by high levels of glycoproteins in mesenchymal subsets of glioblastomas promotes stemness through integrin mechanosignaling pathways (Barnes et al. 2018). Integrin signaling, particularly mediated by integrin $\alpha 7$, maintains GSC proliferation and invasiveness, serving as a therapeutic target (Haas et al. 2017). Additionally, glioma-associated mesenchymal stem cells, a nontumorigenic stromal component of human glioblastomas, support GSCs through an IL-6/STAT3 axis (Hossain et al. 2015) and secretion of microRNA-containing exosomes (Figueroa et al. 2017).

Tumor tissues are composed of a heterogenous population of tumor cells with distinct functional properties. Transcriptomic and genomic mapping efforts of histologically defined anatomic regions of glioblastoma tumors provide a resource to begin to functionally characterize this intratumoral heterogeneity (Puchalski et al. 2018). Intercellular communication plays important roles in the maintenance of the complex cellular systems that compose a tumor. In vivo multiphoton microscopy of glioblastomas in xenograft hosts reveals multicellular anatomic networks composed of "tumor microtubes" connecting glioblastoma cells. These microtubes permit long-range coordinated communication between cells via connexins, providing tracts for invasion, and are required for maintenance of the tumor cell network following therapeutic interventions (Osswald et al. 2015). Functional connexin-mediated gap junctions are essential for GSCs (Hitomi et al. 2015). Communication via secreted factors is also important, as differentiated glioblastoma cells produce BDNF to support the growth and survival of their stem cell counterparts (Wang et al. 2018).

The critical role of the immune system in regulating tumor biology represents one of the most rapidly evolving microenvironmental dependencies. Immune editing of developing tumors by both innate and adaptive arms of the immune system drives the evolution of GSCs as they evade immunosurveillance, while signaling from GSCs can shape their local immune environment. Tumor-associated macrophages (TAMs) stimulate GSC maintenance and tumorigenicity through a pleiotrophin-PTPRZ1 signaling axis (Shi et al. 2017) and promote glycolytic metabolism through an IL6-PGK1 axis (Zhang et al. 2018). Inhibition of this GSC-TAM cross-talk has been explored as a therapeutic avenue through targeting CSF-1R on macrophages (Pyonteck et al. 2013; Quail et al. 2016). GSCs down-regulate expression of innate immune sensors (namely, the toll-like receptor TLR4) to prevent negative modulation of stem-like properties by the immune system (Alvarado et al. 2017) and recruit TAMs that enhance tumor growth and block tumor rejection (Zhou et al. 2015; Otvos et al. 2016). Engineered mouse models of low-grade IDH mutant gliomas demonstrate lower immune infiltration and leukocyte chemotaxis than in IDH wild-type models, suggesting that differential immune activation between low- and high-grade tumors may partially explain the prognostic disparity between these two diseases (Amankulor et al. 2017). Glioblastomas, along with other cancers localized to the brain, mediate profound systemic T-cell deficiency, with $\mathrm{T}$ cells accumulating within bone marrow and unable to traffic to the site of the tumor due to loss of cell surface S1P1 (Chongsathidkiet et al. 2018). Glioblastomas also generate both local and systemic immunosuppression by inducing M2 macrophage polarization and Th2 reactivity that impairs antitumor responses (Prosniak et al. 2013; Harshyne et al. 2016). GSCs evade T-cell killing by secretion of extracellular vesicles containing the T-cell checkpoint molecule PD-L1 (Ricklefs et al. 2018). GSC-derived exosomes may suppress $\mathrm{T}$ cells through monocyte maturation (Domenis et al. 2017). Thus, GSCs use a number of mechanisms to avoid immune-mediated destruction and derive growth benefit from factors derived from the immune microenvironment. 
Targeting GSCs: applying basic research to clinical therapy

The promise of the cancer stem cell hypothesis is that a deeper understanding of this unique cell population that initiates tumors and mediates recurrence following therapy will allow for efficient therapeutic targeting of these cells and survival benefits for patients. Over the past few years, research in preclinical application of these findings has used several therapeutic modalities, including molecular targeting, cell-based drug delivery methods, viral therapy, and immunotherapy, among others (Fig. 5). Telomerase reverse transcriptase (TERT) represents an attractive therapeutic target, as its promoter contains the most recurrent single nucleotide mutation in glioma and many other cancer types (Killela et al. 2013; Vinagre et al. 2013). More recently, binding of the GABP transcription factor to the mutant promoter has been demonstrated as a mechanism for TERT reactivation in glioblastoma (Bell et al. 2015), and this can be targeted with inhibition of this interaction (Mancini et al. 2018). Targeting of the telomere-protecting factor TRF1 by chemical and genetic means can also reduce GSC viability and tumorigenicity and lead to regression of established tumors in mouse models (Bejarano et al. 2017). Targeting of circadian rhythm regulators in the REV-ERB family has also demonstrated efficacy against GSCs and cells from other cancer types in vivo associated with alterations in lipid metabolism and autophagy pathways (Sulli et al. 2018), although the precise roles of the circadian clock remain undefined in GSCs. Autophagy is an important cellular survival mechanism, particularly following exposure to extreme stresses. Targeting a key autophagy regulator, ATG4B, with a small molecule inhibitor enhanced the efficacy of radiation therapy in orthotopic xenograft models (Huang et al. 2017). Secondary glioblastomas contain a high frequency of MET alterations and are sensitive to MET inhibitors, which displayed some efficacy in early clinical trials (Hu et al. 2018).

Oncolytic viral therapy represents a new therapeutic modality with increasing promise. Improved oncolytic adenovirus treatment regimens have demonstrated efficacy in mouse models through stimulating an influx of T cells (Jiang et al. 2017) and in human patients through altering the composition of TAMs (van den Bossche et al. 2018). Modified herpes simplex viruses combined with immune checkpoint inhibition increase $\mathrm{CD} 8^{+}$killer T-cell infiltration and transition to a more inflammatory antitumor macrophage phenotype (Saha et al. 2017). Phase 1 trials of modified poliovirus have demonstrated some efficacy in the treatment of recurrent glioblastoma, with evidence that a subset of patients may gain relatively long-term survival benefit (Desjardins et al. 2018). The highly neurotropic flavivirus Zika virus selectively ablates GSC populations in organoid and mouse models, although concerns surrounding biosafety limit widespread adoption of this virus in clinical trials at the present time (Zhu et al. 2017).

In addition to viral therapies, cell-based therapies are emerging as viable treatment options. Treatment with dendritic cell vaccines containing glioblastoma-specific cytomegalovirus antigens in combination with immune adjuvants extended survival in a small cohort of patients

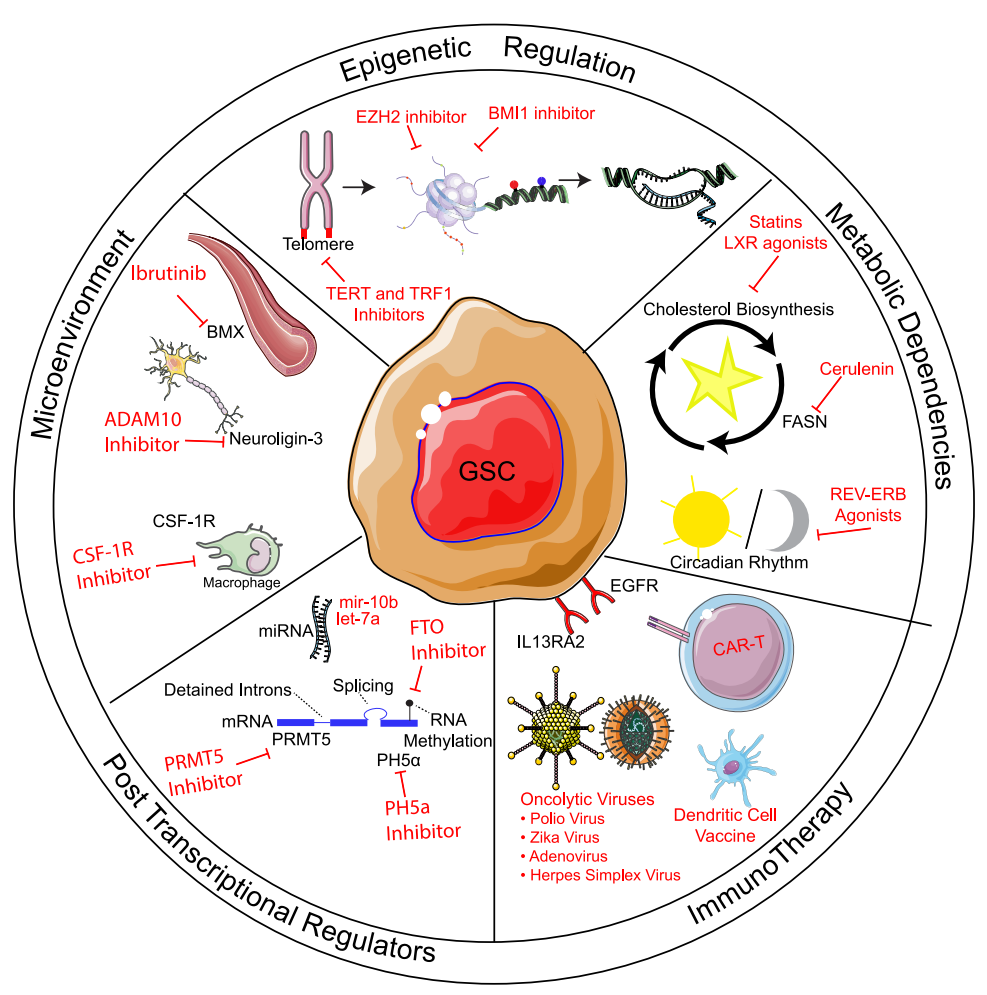

Figure 5. Targeting GSCs. Numerous avenues exist for targeting GSCs, including selectively poisoning epigenetic, metabolic, microenvironmental, posttranscriptional, and immune interactions. 
(Mitchell et al. 2015). Treatment with autologous tumor lysate-containing dendritic cells may also be a feasible approach (Prins et al. 2011). In two early clinical trials, administration of personalized vaccines containing tumor neoepitopes elicited strong T-cell immunologic responses with evidence of immunologic memory and tumor-infiltrating capacity (Hilf et al. 2019; Keskin et al. 2019). Neural stem-like cells engineered from autologous patient-derived fibroblasts home to glioblastoma tumors and deliver cytotoxic compounds to tumor cells in mouse models (Bagó et al. 2017) and have been investigated in early phase clinical trials (Portnow et al. 2017). Chimeric antigen receptor (CAR) T-cell therapy against tumor-specific targets, including IL13RA2 (Brown et al. 2016) and EGFRvIII (O'Rourke et al. 2017), display some efficacy in patients with recurrent glioblastoma without major limiting toxicities in phase 1 clinical trials. In preclinical studies, CAR natural killer (NK) cells targeting EGFR appear to also prolong survival in xenograft-bearing mouse glioblastoma models (Han et al. 2015). While immune checkpoint inhibitors targeting CTLA-4 and the PD-1/PD-L1 axis demonstrate remarkable efficacy in other cancers, their role in glioblastoma remains to be determined pending completion of clinical trials. Thus, utilization of innate and adaptive immune responses to target GSCs and glioblastoma remains an active and fruitful area of ongoing investigation.

\section{Emerging directions and GSC themes}

Over the past $5 \mathrm{yr}$, progress has been made in understanding the epigenetic, metabolic, microenvironmental, and developmental underpinnings of GSCs. These findings have been driven by new technological advances, including the rise of single-cell genomics, which has allowed for an unprecedented characterization of tumor heterogeneity at the epigenomic and transcriptomic levels. The emergence of CRISPR-Cas9 genome-editing tools and derivatives has enhanced our ability to precisely perturb our cellular models and read out effects in a high-throughput manner. Thus, the burden of screening large sets of genes or genomic regions in a variety of cellular contexts has been dramatically reduced. The role of the immune system as a critical regulator of tumor biology and an essential component of therapeutic intervention has come into sharper focus. Immune checkpoint inhibition and cellbased therapies, including CAR-T cells, must be investigated further in the coming years.

However, despite the deluge of basic science publications purporting to uncover the next greatest molecular target for glioblastoma therapy, few targets have been effectively translated into clinical care. Glioblastoma patient survival has increased only marginally since the addition of temozolomide and radiation, and the disease remains uniformly fatal. Many obstacles remain that are beyond the scope of this review, including scientific reproducibility issues, poorly aligned incentive structures that do not always reward the most high-impact investigation, and the immense cost and time required to translate a potential target into clinical practice (Kaelin 2017). We fo- cused on several outstanding challenges here, which revolve around a single major issue: our current inability to effectively model the heterogenous patient disease. First, a large proportion of glioblastoma studies continue to use cell lines that have been cultured in artificial conditions. These experiments almost certainly fail to recapitulate the patient disease, as one prominently used model, U87MG, has an unknown origin (Allen et al. 2016). Second, even if low-passage patient-derived xenograft models are used for study, clonal selection following in vitro culture rapidly depletes cellular heterogeneity. This prevents the field from effectively modeling tumor heterogeneity and may explain why certain therapies perform well in relatively homogenous tumor models but fail in real-world heterogenous tumors in patients. Third, in vitro studies are frequently conducted in hyperoxic, hyperglycemic, and otherwise nonphysiologic conditions that are devoid of normal cell-cell interactions. Increased use of organoid model systems and other tools to perform high-throughput and high-fidelity tumor modeling will be essential to overcome this challenge. Fourth, modeling of the specialized immune-tumor cell interactions has been limited by the field's inability to study the effects of a human immune system on human tumors in a model organism. These challenges, while difficult, are not insurmountable and must be addressed to ensure that basic science research can be relevant beyond the benchtop and inform patient management.

\section{Acknowledgments}

We apologize to the authors of the many outstanding publications not referenced here due to space restrictions. Figures were prepared in part using images from Servier Medical Art by Servier (https://smart.servier.com), which is licensed under a Creative Commons Attribution 3.0 Unported License (https:// creativecommons.org/licenses/by/3.0). This work was supported by grants provided by the National Institutes of Health (CA217065 to R.C.G. and CA197718, CA154130, CA169117, CA171652, NS087913, NS089272, and NS103434 to J.N.R.).

\section{References}

Alcantara Llaguno S, Chen J, Kwon CH, Jackson EL, Li Y, Burns DK, Alvarez-Buylla A, Parada LF. 2009. Malignant astrocytomas originate from neural stem/progenitor cells in a somatic tumor suppressor mouse model. Cancer Cell 15: 45-56. doi:10.1016/j.ccr.2008.12.006

Alcantara Llaguno SR, Wang Z, Sun D, Chen J, Xu J, Kim E, Hatanpaa KJ, Raisanen JM, Burns DK, Johnson JE, et al. 2015. Adult lineage-restricted CNS progenitors specify distinct glioblastoma subtypes. Cancer Cell 28: 429-440. doi:10 .1016/j.ccell.2015.09.007

Al-Haji M, Wicha MS, Benito-Hernandez A, Morrison SJ, Clarke MF. 2003. Prospective identification of tumorigenic breast cancer cells. Proc Natl Acad Sci 100: 3983-3988. doi:10 $.1073 /$ pnas.0530291100

Allen M, Bjerke M, Edlund H, Nelander S, Westermark B. 2016. Origin of the U87MG glioma cell line: good news and bad news. Sci Trans1 Med 8: 354re353. doi:10.1126/scitranslmed .aff6853 
Alvarado AG, Thiagarajan PS, Mulkearns-Hubert EE, Silver DI, Hale JS, Alban TJ, Turaga SM, Jarrar A, Reizes O, Longworth MS, et al. 2017. Glioblastoma cancer stem cells evade innate immune suppression of self-renewal through reduced TLR4 expression. Cell Stem Cell 20: 450-461.e4. doi:10.1016/j .stem.2016.12.001

Amankulor NM, Kim Y, Arora S, Kargl J, Szulzewsky F, Hanke M, Margineantu DH, Rao A, Bolouri H, Delrow J, et al. 2017. Mutant IDH1 regulates the tumor-associated immune system in gliomas. Genes Dev 31: 774-786. doi:10.1101/gad.294991.116

Anthiya S, Griveau A, Loussouarn C, Baril P, Garnett M, Issartel JP, Garcion E. 2018. MicroRNA-based drugs for brain tumors. Trends Cancer 4: 222-238. doi:10.1016/j.trecan.2017.12.008

Bachoo RM, Maher EA, Ligon KL, Sharpless NE, Chan SS, You MJ, Tang Y, DeFrances J, Stover E, Weissleder R, et al. 2002. Epidermal growth factor receptor and Ink4a/Arf: convergent mechanisms governing terminal differentiation and transformation along the neural stem cell to astrocyte axis. Cancer Cell 1: 269-277. doi:10.1016/S1535-6108(02)00046-6

Bagó JR, Okolie O, Dumitru R, Ewend MG, Parker JS, Werff RV, Underhill TM, Schmid RS, Miller CR, Hingtgen SD. 2017. Tumor-homing cytotoxic human induced neural stem cells for cancer therapy. Sci Transl Med 9: eaah6510. doi:10.1126/sci translmed.aah6510

Bao S, Wu Q, McLendon RE, Hao Y, Shi Q, Hjelmeland AB, Dewhirst MW, Bigner DD, Rich JN. 2006a. Glioma stem cells promote radioresistance by preferential activation of the DNA damage response. Nature 444: 756-760. doi:10.1038/ nature 05236

Bao S, Wu Q, Sathornsumetee S, Hao Y, Li Z, Hjelmeland AB, Shi Q, McLendon RE, Bigner DD, Rich JN. 2006b. Stem cell-like glioma cells promote tumor angiogenesis through vascular endothelial growth factor. Cancer Res 66: 7843-7848. doi:10 .1158/0008-5472.CAN-06-1010

Bardella C, Al-Dalahmah O, Krell D, Brazauskas P, Al-Qahtani K, Tomkova M, Adam J, Serres S, Lockstone H, Freeman-Mills L, et al. 2016. Expression of Idh1(R132H) in the murine subventricular zone stem cell niche recapitulates features of early gliomagenesis. Cancer Cell 30: 578-594. doi:10.1016/j.ccell .2016.08.017

Barnes JM, Kaushik S, Bainer RO, Sa JK, Woods EC, Kai F, Przybyla L, Lee M, Lee HW, Tung JC, et al. 2018. A tensionmediated glycocalyx-integrin feedback loop promotes mesenchymal-like glioblastoma. Nat Cell Biol 20: 1203-1214. doi:10 .1038/s41556-018-0183-3

Beier D, Hau P, Proescholdt M, Lohmeier A, Wischhusen J, Oefner PJ, Aigner L, Brawanski A, Bogdahn U, Beier CP. 2007. $\mathrm{CD}_{133^{+}}$and $\mathrm{CD}_{133^{-}}$glioblastoma-derived cancer stem cells show differential growth characteristics and molecular profiles. Cancer Res 67: 4010-4015. doi:10.1158/0008-5472 .CAN-06-4180

Bejarano L, Schuhmacher AJ, Méndez M, Megías D, Blanco-Aparicio C, Martínez S, Pastor J, Squatrito M, Blasco MA. 2017. Inhibition of TRF1 telomere protein impairs tumor initiation and progression in glioblastoma mouse models and patientderived xenografts. Cancer Cell 32: 590-607.e4. doi:10.1016/ j.ccell.2017.10.006

Bell RJ, Rube HT, Kreig A, Mancini A, Fouse SD, Nagarajan RP, Choi S, Hong C, He D, Pekmezci M, et al. 2015. Cancer. The transcription factor GABP selectively binds and activates the mutant TERT promoter in cancer. Science 348: 10361039. doi:10.1126/science.aab0015

Ben-David U, Ha G, Tseng YY, Greenwald NF, Oh C, Shih J, McFarland JM, Wong B, Boehm JS, Beroukhim R, et al. 2017.
Patient-derived xenografts undergo mouse-specific tumor evolution. Nat Genet 49: 1567-1575. doi:10.1038/ng.3967

Benitez JA, Ma J, D'Antonio M, Boyer A, Camargo MF, Zanca C, Kelly S, Khodadadi-Jamayran A, Jameson NM, Andersen M, et al. 2017. PTEN regulates glioblastoma oncogenesis through chromatin-associated complexes of DAXX and histone H3.3. Nat Commun 8: 15223. doi:10.1038/ncomms15223

Bian S, Repic M, Guo Z, Kavirayani A, Burkard T, Bagley JA, Krauditsch C, Knoblich JA. 2018. Genetically engineered cerebral organoids model brain tumor formation. Nat Methods 15: 631-639. doi:10.1038/s41592-018-0070-7

Bidlingmaier S, Zhu X, Liu B. 2008. The utility and limitations of glycosylated human CD133 epitopes in defining cancer stem cells. I Mol Med (Berl) 86: 1025-1032. doi:10.1007/s00109008-0357-8

Bonnet D, Dick JE. 1997. Human acute myeloid leukemia is organized as a hierarchy that originates from a primitive hematopoietic cell. Nat Med 3: 730-737. doi:10.1038/nm0797-730

Braun CJ, Stanciu M, Boutz PL, Patterson JC, Calligaris D, Higuchi F, Neupane R, Fenoglio S, Cahill DP, Wakimoto H, et al. 2017. Coordinated splicing of regulatory detained introns within oncogenic transcripts creates an exploitable vulnerability in malignant glioma. Cancer Cell 32: 411-426.e11. doi:10.1016/j.ccell.2017.08.018

Brennan CW, Verhaak RG, McKenna A, Campos B, Noushmehr H, Salama SR, Zheng S, Chakravarty D, Sanborn JZ, Berman $\mathrm{SH}$, et al. 2013. The somatic genomic landscape of glioblastoma. Cell 155: 462-477. doi:10.1016/j.cell.2013.09.034

Brescia P, Richichi C, Pelicci G. 2012. Current strategies for identification of glioma stem cells: adequate or unsatisfactory? $J$ Oncol 2012: 376894. doi:10.1155/2012/376894

Brown CE, Alizadeh D, Starr R, Weng L, Wagner JR, Naranjo A, Ostberg JR, Blanchard MS, Kilpatrick J, Simpson J, et al. 2016. Regression of glioblastoma after chimeric antigen receptor T-cell therapy. N Engl J Med 375: 2561-2569. doi:10.1056/ NEJMoal610497

Bulstrode $\mathrm{H}$, Johnstone E, Marques-Torrejon MA, Ferguson KM, Bressan RB, Blin C, Grant V, Gogolok S, Gangoso E, Gagrica $S$, et al. 2017. Elevated FOXG1 and SOX2 in glioblastoma enforces neural stem cell identity through transcriptional control of cell cycle and epigenetic regulators. Genes Dev 31: 757-773. doi:10.1101/gad.293027.116

Ceccarelli M, Barthel FP, Malta TM, Sabedot TS, Salama SR, Murray BA, Morozova O, Newton Y, Radenbaugh A, Pagnotta SM, et al. 2016. Molecular profiling reveals biologically discrete subsets and pathways of progression in diffuse glioma. Cell 164: 550-563. doi:10.1016/j.cell.2015.12.028

Chen J, Li Y, Yu TS, McKay RM, Burns DK, Kernie SG, Parada LF. 2012. A restricted cell population propagates glioblastoma growth after chemotherapy. Nature 488: 522-526. doi:10 $.1038 /$ nature 11287

Chen Q, Cai J, Wang Q, Wang Y, Liu M, Yang J, Zhou J, Kang C, Li $\mathrm{M}$, Jiang C. 2018. Long noncoding RNA NEAT1, regulated by the EGFR pathway, contributes to glioblastoma progression through the WNT/ $\beta$-catenin pathway by scaffolding EZH2. Clin Cancer Res 24: 684-695. doi:10.1158/1078-0432.CCR17-0605

Cheng L, Huang Z, Zhou W, Wu Q, Donnola S, Liu JK, Fang X, Sloan AE, Mao Y, Lathia JD, et al. 2013. Glioblastoma stem cells generate vascular pericytes to support vessel function and tumor growth. Cell 153: 139-152. doi:10.1016/j.cell .2013.02.021

Cheng C, Ru P, Geng F, Liu J, Yoo JY, Wu X, Cheng X, Euthine V, Hu P, Guo JY, et al. 2015. Glucose-mediated N-glycosylation 
of SCAP is essential for SREBP-1 activation and tumor growth. Cancer Cell 28: 569-581. doi:10.1016/j.ccell.2015.09.021

Chhipa RR, Fan Q, Anderson J, Muraleedharan R, Huang Y, Ciraolo G, Chen X, Waclaw R, Chow LM, Khuchua Z, et al. 2018. AMP kinase promotes glioblastoma bioenergetics and tumour growth. Nat Cell Biol 20: 823-835. doi:10.1038/ s41556-018-0126-z

Chongsathidkiet P, Jackson C, Koyama S, Loebel F, Cui X, Farber SH, Woroniecka K, Elsamadicy AA, Dechant CA, Kemeny $\mathrm{HR}$, et al. 2018. Sequestration of $\mathrm{T}$ cells in bone marrow in the setting of glioblastoma and other intracranial tumors. Nat Med 24: 1459-1468. doi:10.1038/s41591-018-0135-2

Chow RD, Guzman CD, Wang G, Schmidt F, Youngblood MW, Ye L, Errami Y, Dong MB, Martinez MA, Zhang S, et al. 2017. AAV-mediated direct in vivo CRISPR screen identifies functional suppressors in glioblastoma. Nat Neurosci 20: 1329-1341. doi:10.1038/nn.4620

Collins AT, Berry PA, Hyde C, Stower MJ, Maitland NJ. 2005. Prospective identification of tumorigenic prostate cancer stem cells. Cancer Res 65: 10946-10951. doi:10.1158/0008-5472 .CAN-05-2018

Correa BR, de Araujo PR, Qiao M, Burns SC, Chen C, Schlegel R, Agarwal S, Galante PA, Penalva LO. 2016. Functional genomics analyses of RNA-binding proteins reveal the splicing regulator SNRPB as an oncogenic candidate in glioblastoma. Genome Biol 17: 125. doi:10.1186/s13059-016-0990-4

Cosset É, Ilmjärv S, Dutoit V, Elliott K, von Schalscha T, Camargo MF, Reiss A, Moroishi T, Seguin L, Gomez G, et al. 2017. Glut3 addiction is a druggable vulnerability for a molecularly defined subpopulation of glioblastoma. Cancer Cell 32: 856868.e5. doi:10.1016/j.ccell.2017.10.016

Cui Q, Shi H, Ye P, Li L, Qu Q, Sun G, Sun G, Lu Z, Huang Y, Yang CG, et al. 2017. m6 A RNA methylation regulates the self-renewal and tumorigenesis of glioblastoma stem cells. Cell Rep 18: 2622-2634. doi:10.1016/j.celrep.2017.02.059

De Rosa A, Pellegatta S, Rossi M, Tunici P, Magnoni L, Speranza MC, Malusa F, Miragliotta V, Mori E, Finocchiaro G, et al. 2012. A radial glia gene marker, fatty acid binding protein 7 (FABP7), is involved in proliferation and invasion of glioblastoma cells. PLoS One 7: e52113. doi:10.1371/journal.pone .0052113

Desjardins A, Gromeier M, Herndon JE II, Beaubier N, Bolognesi DP, Friedman AH, Friedman HS, McSherry F, Muscat AM, Nair S, et al. 2018. Recurrent glioblastoma treated with recombinant poliovirus. $N$ Engl J Med 379: 150-161. doi:10 $.1056 /$ NEJMoa1716435

Dolma S, Selvadurai HJ, Lan X, Lee L, Kushida M, Voisin V, Whetstone H, So M, Aviv T, Park N, et al. 2016. Inhibition of dopamine receptor D4 impedes autophagic flux, proliferation, and survival of glioblastoma stem cells. Cancer Cell 29: 859-873. doi:10.1016/j.ccell.2016.05.002

Domenis R, Cesselli D, Toffoletto B, Bourkoula E, Caponnetto F, Manini I, Beltrami AP, Ius T, Skrap M, Di Loreto C, et al. 2017. Systemic T cells immunosuppression of glioma stem cell-derived exosomes is mediated by monocytic myeloid-derived suppressor cells. PLoS One 12: e0169932. doi:10.1371/jour nal.pone.0169932

Dominissini D, Moshitch-Moshkovitz S, Schwartz S, SalmonDivon M, Ungar L, Osenberg S, Cesarkas K, Jacob-Hirsch J, Amariglio N, Kupiec M, et al. 2012. Topology of the human and mouse $\mathrm{m}^{6} \mathrm{~A}$ RNA methylomes revealed by $\mathrm{m}^{6} \mathrm{~A}$-seq. Nature 485: 201-206. doi:10.1038/nature11112

Duan S, Yuan G, Liu X, Ren R, Li J, Zhang W, Wu J, Xu X, Fu L, Li $Y$, et al. 2015. PTEN deficiency reprogrammes human neural stem cells towards a glioblastoma stem cell-like phenotype. Nat Commun 6: 10068. doi:10.1038/ncomms10068

Figueroa J, Phillips LM, Shahar T, Hossain A, Gumin J, Kim H, Bean AJ, Calin GA, Fueyo J, Walters ET, et al. 2017. Exosomes from glioma-associated mesenchymal stem cells increase the tumorigenicity of glioma stem-like cells via transfer of miR1587. Cancer Res 77: 5808-5819. doi:10.1158/0008-5472 .CAN-16-2524

Filbin MG, Tirosh I, Hovestadt V, Shaw ML, Escalante LE, Mathewson ND, Neftel C, Frank N, Pelton K, Hebert CM, et al. 2018. Developmental and oncogenic programs in H3K27M gliomas dissected by single-cell RNA-seq. Science 360: 331335. doi:10.1126/science.aao4750

Flavahan WA, Wu Q, Hitomi M, Rahim N, Kim Y, Sloan AE, Weil RJ, Nakano I, Sarkaria JN, Stringer BW, et al. 2013. Brain tumor initiating cells adapt to restricted nutrition through preferential glucose uptake. Nat Neurosci 16: 1373-1382. doi:10 $.1038 / \mathrm{nn} .3510$

Frattini V, Pagnotta SM, Tala FJ, Russo MV, Lee SB, Garofano L, Zhang J, Shi P, Lewis G, et al. 2018. A metabolic function of FGFR3-TACC3 gene fusions in cancer. Nature 553: 222-227. doi:10.1038/nature25171

Furth J, Kahn M, Breedis C. 1937. The transmission of leukemia of mice with a single cell. Am J Cancer 31: 276-282.

Galli R, Binda E, Orfanelli U, Cipelletti B, Gritti A, De Vitis S, Fiocco R, Foroni C, Dimeco F, Vescovi A. 2004. Isolation and characterization of tumorigenic, stem-like neural precursors from human glioblastoma. Cancer Res 64: 7011-7021. doi:10.1158/0008-5472.CAN-04-1364

Gallo M, Coutinho FJ, Vanner RJ, Gayden T, Mack SC, Murison A, Remke M, Li R, Takayama N, Desai K, et al. 2015. MLL5 orchestrates a cancer self-renewal state by repressing the histone variant $\mathrm{H} 3.3$ and globally reorganizing chromatin. Cancer Cell 28: 715-729. doi:10.1016/j.ccell.2015.10.005

Gao X, Lin SH, Ren F, Li JT, Chen JJ, Yao CB, Yang HB, Jiang SX, Yan GQ, Wang D, et al. 2016. Acetate functions as an epigenetic metabolite to promote lipid synthesis under hypoxia. Nat Commun 7: 11960. doi:10.1038/ncomms11960

Gilbert CA, Ross AH. 2009. Cancer stem cells: cell culture, markers, and targets for new therapies. J Cell Biochem 108: 10311038. doi: $10.1002 /$ jcb. 22350

Griveau A, Seano G, Shelton SJ, Kupp R, Jahangiri A, Obernier K, Krishnan S, Lindberg OR, Yuen TJ, Tien AC, et al. 2018. A glial signature and Wnt7 signaling regulate glioma-vascular interactions and tumor microenvironment. Cancer Cell 33: 874-889.e7. doi:10.1016/j.ccell.2018.03.020

Guo D, Prins RM, Dang J, Kuga D, Iwanami A, Soto H, Lin KY, Huang TT, Akhavan D, Hock MB, et al. 2009. EGFR signaling through an Akt-SREBP-1-dependent, rapamycin-resistant pathway sensitizes glioblastomas to antilipogenic therapy. Sci Signal 2: ra82. doi:10.1126/scisignal.2000446

Haas TL, Sciuto MR, Brunetto L, Valvo C, Signore M, Fiori ME, di Martino S, Giannetti S, Morgante L, Boe A, et al. 2017. Integrin $\alpha 7$ is a functional marker and potential therapeutic target in glioblastoma. Cell Stem Cell 21: 35-50.e9. doi:10.1016/j .stem.2017.04.009

Halle B, Marcusson EG, Aaberg-Jessen C, Jensen SS, Meyer M, Schulz MK, Andersen C, Kristensen BW. 2016. Convectionenhanced delivery of an anti-miR is well-tolerated, preserves anti-miR stability and causes efficient target de-repression: a proof of concept. I Neurooncol 126: 47-55. doi:10.1007/ s1 1060-015-1947-2

Hambardzumyan D, Amankulor NM, Helmy KY, Becher OJ, Holland EC. 2009. Modeling adult gliomas using RCAS/t-va technology. Transl Oncol 2: 89-95. doi:10.1593/tlo.09100 
Han J, Chu J, Keung Chan W, Zhang J, Wang Y, Cohen JB, Victor A, Meisen WH, Kim SH, Grandi P, et al. 2015. CARengineered NK cells targeting wild-type EGFR and EGFRvIII enhance killing of glioblastoma and patient-derived glioblastoma stem cells. Sci Rep 5: 11483. doi:10.1038/srep11483

Hanahan D, Weinberg RA. 2011. Hallmarks of cancer: the next generation. Cell 144: 646-674. doi:10.1016/j.cell.2011.02.013

Harshyne LA, Nasca BJ, Kenyon LC, Andrews DW, Hooper DC. 2016. Serum exosomes and cytokines promote a T-helper cell type 2 environment in the peripheral blood of glioblastoma patients. Neuro Oncol 18: 206-215. doi:10.1093/neuonc/ nov107

Hemmati HD, Nakano I, Lazareff JA, Masterman-Smith M, Geschwind DH, Bronner-Fraser M, Kornblum HI. 2003. Cancerous stem cells can arise from pediatric brain tumors. Proc Natl Acad Sci 100: 15178-15183. doi:10.1073/pnas .2036535100

Hentze MW, Castello A, Schwarzl T, Preiss T. 2018. A brave new world of RNA-binding proteins. Nat Rev Mol Cell Biol 19: 327-341. doi:10.1038/nrm.2017.130

Hidalgo M, Amant F, Biankin AV, Budinska E, Byrne AT, Caldas C, Clarke RB, de Jong S, Jonkers J, Maelandsmo GM, et al. 2014. Patient-derived xenograft models: an emerging platform for translational cancer research. Cancer Discov 4: 998-1013. doi:10.1158/2159-8290.CD-14-0001

Hilf N, Kuttruff-Coqui S, Frenzel K, Bukur V, Stevanović S, Gouttefangeas C, Platten M, Tabatabai G, Dutoit V, van der Burg $\mathrm{SH}$, et al. 2019. Actively personalized vaccination trial for newly diagnosed glioblastoma. Nature 565: 240-245. doi:10 .1038/s41586-018-0810-y

Hitomi M, Deleyrolle LP, Mulkearns-Hubert EE, Jarrar A, Li M, Sinyuk M, Otvos B, Brunet S, Flavahan WA, Hubert CG, et al. 2015. Differential connexin function enhances self-renewal in glioblastoma. Cell Rep 11: 1031-1042. doi:10.1016/ j.celrep.2015.04.021

Hoang-Minh LB, Siebzehnrubl FA, Yang C, Suzuki-Hatano S, Dajac K, Loche T, Andrews N, Schmoll Massari M, Patel J, Amin $\mathrm{K}$, et al. 2018. Infiltrative and drug-resistant slowcycling cells support metabolic heterogeneity in glioblastoma. EMBO J 37: e98772. doi:10.15252/embj.201798772

Holash J, Maisonpierre PC, Compton D, Boland P, Alexander CR, Zagzag D, Yancopoulos GD, Wiegand SJ. 1999. Vessel cooption, regression, and growth in tumors mediated by angiopoietins and VEGF. Science 284: 1994-1998. doi:10.1126/science .284 .5422 .1994

Holland EC, Celestino J, Dai C, Schaefer L, Sawaya RE, Fuller GN. 2000. Combined activation of Ras and Akt in neural progenitors induces glioblastoma formation in mice. Nat Genet 25: 55-57. doi:10.1038/75596

Hossain A, Gumin J, Gao F, Figueroa J, Shinojima N, Takezaki T, Priebe W, Villarreal D, Kang SG, Joyce C, et al. 2015. Mesenchymal stem cells isolated from human gliomas increase proliferation and maintain stemness of glioma stem cells through the IL-6/gp130/STAT3 pathway. Stem Cells 33: 2400-2415. doi:10.1002/stem.2053

Hu B, Wang Q, Wang YA, Hua S, Sauvé CG, Ong D, Lan ZD, Chang Q, Ho YW, Monasterio MM, et al. 2016. Epigenetic activation of WNT5A drives glioblastoma stem cell differentiation and invasive growth. Cell 167: 1281-1295.e18. doi:10 $.1016 /$ j.cell.2016.10.039

Hu H, Mu Q, Bao Z, Chen Y, Liu Y, Chen J, Wang K, Wang Z, Nam $\mathrm{Y}$, Jiang B, et al. 2018. Mutational landscape of secondary glioblastoma guides MET-targeted trial in brain tumor. Cell 175: 1665-1678.e18. doi:10.1016/j.cell.2018.09.038
Huang T, Kim CK, Alvarez AA, Pangeni RP, Wan X, Song X, Shi T, Yang Y, Sastry N, Horbinski CM, et al. 2017. MST4 phosphorylation of ATG4B regulates autophagic activity, tumorigenicity, and radioresistance in glioblastoma. Cancer Cell 32: 840-855.e8. doi:10.1016/j.ccell.2017.11.005

Hubert CG, Bradley RK, Ding Y, Toledo CM, Herman J, SkuttKakaria K, Girard EJ, Davison J, Berndt J, Corrin P, et al. 2013. Genome-wide RNAi screens in human brain tumor isolates reveal a novel viability requirement for $\mathrm{PHF}_{5} \mathrm{~A}$. Genes Dev 27: 1032-1045. doi:10.1101/gad.212548.112

Hubert CG, Rivera M, Spangler LC, Wu Q, Mack SC, Prager BC, Couce M, McLendon RE, Sloan AE, Rich JN. 2016. A three-dimensional organoid culture system derived from human glioblastomas recapitulates the hypoxic gradients and cancer stem cell heterogeneity of tumors found in vivo. Cancer Res 76: 2465-2477. doi:10.1158/0008-5472.CAN-15-2402

Huse JT, Holland EC. 2009. Yin and yang: cancer-implicated miRNAs that have it both ways. Cell Cycle 8: 3611-3612. doi:10 $.4161 /$ cc.8.22.9893

Janiszewska M, Suva ML, Riggi N, Houtkooper RH, Auwerx J, Clement-Schatlo V, Radovanovic I, Rheinbay E, Provero P, Stamenkovic I. 2012. Imp2 controls oxidative phosphorylation and is crucial for preserving glioblastoma cancer stem cells. Genes Dev 26: 1926-1944. doi:10.1101/gad.188292.112

Jiang H, Rivera-Molina Y, Gomez-Manzano C, Clise-Dwyer K, Bover L, Vence LM, Yuan Y, Lang FF, Toniatti C, Hossain $\mathrm{MB}$, et al. 2017. Oncolytic adenovirus and tumor-targeting immune modulatory therapy improve autologous cancer vaccination. Cancer Res 77: 3894-3907. doi:10.1158/0008-5472 .CAN-17-0468

Jin X, Kim LJY, Wu Q, Wallace LC, Prager BC, Sanvoranart T, Gimple RC, Wang X, Mack SC, Miller TE, et al. 2017. Targeting glioma stem cells through combined BMI1 and EZH2 inhibition. Nat Med 23: 1352-1361. doi:10.1038/nm.4415

Jung J, Kim LJY, Wang X, Wu Q, Sanvoranart T, Hubert CG, Prager BC, Wallace LC, Jin X, Mack SC, et al. 2017. Nicotinamide metabolism regulates glioblastoma stem cell maintenance. JCI insight 2: 90019. doi:10.1172/jci.insight.90019

Jung J, Seol HS, Chang S. 2018. The generation and application of patient-derived xenograft model for cancer research. Cancer Res Treat 50: 1-10. doi:10.4143/crt.2017.307

Kaelin WG Jr. 2017. Common pitfalls in preclinical cancer target validation. Nat Rev Cancer 17: 425-440. doi:10.1038/nrc .2017 .32

Keskin DB, Anandappa AJ, Sun J, Tirosh I, Mathewson ND, Li S, Oliveira G, Giobbie-Hurder A, Felt K, Gjini E, et al. 2019. Neoantigen vaccine generates intratumoral $\mathrm{T}$ cell responses in phase Ib glioblastoma trial. Nature 565: 234-239. doi:10 .1038/s41586-018-0792-9

Killela PJ, Reitman ZJ, Jiao Y, Bettegowda C, Agrawal N, Diaz LA Jr, Friedman AH, Friedman H, Gallia GL, Giovanella BC, et al. 2013. TERT promoter mutations occur frequently in gliomas and a subset of tumors derived from cells with low rates of self-renewal. Proc Natl Acad Sci 110: 6021-6026. doi:10 $.1073 /$ pnas. 1303607110

Kim D, Fiske BP, Birsoy K, Freinkman E, Kami K, Possemato RL, Chudnovsky Y, Pacold ME, Chen WW, Cantor JR, et al. 2015a. SHMT2 drives glioma cell survival in ischaemia but imposes a dependence on glycine clearance. Nature 520:363-367. doi:10 .1038 /nature 14363

Kim J, Lee IH, Cho HJ, Park CK, Jung YS, Kim Y, Nam SH, Kim BS, Johnson MD, Kong DS, et al. 2015b. Spatiotemporal evolution of the primary glioblastoma genome. Cancer Cell 28: 318-328. doi:10.1016/j.ccell.2015.07.013 
Klughammer J, Kiesel B, Roetzer T, Fortelny N, Nemc A, Nenning KH, Furtner J, Sheffield NC, Datlinger P, Peter N, et al. 2018. The DNA methylation landscape of glioblastoma disease progression shows extensive heterogeneity in time and space. Nat Med 24: 1611-1624. doi:10.1038/s41591-0180156-x

Kouri FM, Hurley LA, Daniel WL, Day ES, Hua Y, Hao L, Peng CY, Merkel TJ, Queisser MA, Ritner C, et al. 2015. miR-182 integrates apoptosis, growth, and differentiation programs in glioblastoma. Genes Dev 29: 732-745. doi:10.1101/gad .257394 .114

Krusche B, Ottone C, Clements MP, Johnstone ER, Goetsch K, Lieven H, Mota SG, Singh P, Khadayate S, Ashraf A, et al. 2016. EphrinB2 drives perivascular invasion and proliferation of glioblastoma stem-like cells. eLife 5: e14845. doi:10.7554/ eLife. 14845

Lan X, Jörg DJ, Cavalli FMG, Richards LM, Nguyen LV, Vanner RJ, Guilhamon P, Lee L, Kushida MM, Pellacani D, et al. 2017. Fate mapping of human glioblastoma reveals an invariant stem cell hierarchy. Nature 549: 227-232. doi:10.1038/ nature 23666

Langer EM, Allen-Petersen BL, King SM, Kendsersky ND, Turnidge MA, Kuziel GM, Riggers R, Samatham R, Amery TS, Jacques SL, et al. 2019. Modeling tumor phenotypes in vitro with three-dimensional bioprinting. Cell Rep 26: 608-623.e6. doi:10.1016/j.celrep.2018.12.090

Lapidot T, Sirard C, Vormoor J, Murdoch B, Hoang T, CaceresCortes J, Minden M, Paterson B, Caligiuri MA, Dick JE. 1994. A cell initiating human acute myeloid leukaemia after transplantation into SCID mice. Nature 367: 645-648. doi: $10.1038 / 367645 \mathrm{aO}$

Lee J, Kotliarova S, Kotliarov Y, Li A, Su Q, Donin NM, Pastorino S, Purow BW, Christopher N, Zhang W, et al. 2006. Tumor stem cells derived from glioblastomas cultured in bFGF and EGF more closely mirror the phenotype and genotype of primary tumors than do serum-cultured cell lines. Cancer Cell 9: 391-403. doi:10.1016/j.ccr.2006.03.030

Lee SB, Frattini V, Bansal M, Castano AM, Sherman D, Hutchinson K, Bruce JN, Califano A, Liu G, Cardozo T, et al. 2016. An ID2-dependent mechanism for VHL inactivation in cancer. Nature 529: 172-177. doi:10.1038/nature16475

Lee JH, Lee JE, Kahng JY, Kim SH, Park JS, Yoon SI, Um JY, Kim WK, Lee JK, Park J, et al. 2018. Human glioblastoma arises from subventricular zone cells with low-level driver mutations. Nature 560: 243-247. doi:10.1038/s41586-018-0389-3

Li C, Heidt DG, Dalerba P, Burant CF, Zhang L, Adsay V, Wicha M, Clarke MF, Simeone DM. 2007. Identification of pancreatic cancer stem cells. Cancer Res 67: 1030-1037. doi:10.1158/ 0008-5472.CAN-06-2030

Li X, Yu W, Qian X, Xia Y, Zheng Y, Lee JH, Li W, Lyu J, Rao G, Zhang X, et al. 2017a. Nucleus-translocated ACSS2 promotes gene transcription for lysosomal biogenesis and autophagy. Mol Cell 66: 684-697.e9. doi:10.1016/j.molcel.2017.04.026

Li Z, Weng H, Su R, Weng X, Zuo Z, Li C, Huang H, Nachtergaele S, Dong L, Hu C, et al. 2017b. FTO plays an oncogenic role in acute myeloid leukemia as a $N^{6}$-methyladenosine RNA demethylase. Cancer Cell 31: 127-141. doi:10.1016/j.ccell .2016 .11 .017

Liau BB, Sievers C, Donohue LK, Gillespie SM, Flavahan WA, Miller TE, Venteicher AS, Hebert CH, Carey CD, Rodig SJ, et al. 2017. Adaptive chromatin remodeling drives glioblastoma stem cell plasticity and drug tolerance. Cell Stem Cell 20: 233-246.e7. doi:10.1016/j.stem.2016.11.003

Liu G, Yuan X, Zeng Z, Tunici P, Ng H, Abdulkadir IR, Lu L, Irvin D, Black KL, Yu JS. 2006. Analysis of gene expression and che- moresistance of $\mathrm{CD}_{133^{+}}$cancer stem cells in glioblastoma. Mol Cancer 5: 67. doi:10.1186/1476-4598-5-67

Liu F, Hon GC, Villa GR, Turner KM, Ikegami S, Yang H, Ye Z, Li B, Kuan S, Lee AY, et al. 2015. EGFR mutation promotes glioblastoma through epigenome and transcription factor network remodeling. Mol Cell 60: 307-318. doi:10.1016/j .molcel.2015.09.002

Lu KV, Chang JP, Parachoniak CA, Pandika MM, Aghi MK, Meyronet D, Isachenko N, Fouse SD, Phillips JJ, Cheresh DA, et al. 2012. VEGF inhibits tumor cell invasion and mesenchymal transition through a MET/VEGFR2 complex. Cancer Cell 22: 21-35. doi:10.1016/j.ccr.2012.05.037

Mack SC, Pajtler KW, Chavez L, Okonechnikov K, Bertrand KC, Wang X, Erkek S, Federation A, Song A, Lee C, et al. 2018. Therapeutic targeting of ependymoma as informed by oncogenic enhancer profiling. Nature 553: 101-105. doi:10.1038/ nature 25169

Man J, Yu X, Huang H, Zhou W, Xiang C, Huang H, Miele L, Liu Z, Bebek G, Bao S, et al. 2018. Hypoxic induction of vasorin regulates notch 1 turnover to maintain glioma stem-like cells. Cell Stem Cell 22: 104-118.e6. doi:10.1016/j.stem.2017.10 .005

Mancini A, Xavier-Magalhães A, Woods WS, Nguyen KT, Amen AM, Hayes JL, Fellmann C, Gapinske M, McKinney AM, Hong C, et al. 2018. Disruption of the $\beta 1 \mathrm{~L}$ Isoform of GABP reverses glioblastoma replicative immortality in a TERT promoter mutation-dependent manner. Cancer Cell 34: 513528.e8. doi:10.1016/j.ccell.2018.08.003

Mashimo T, Pichumani K, Vemireddy V, Hatanpaa KJ, Singh DK, Sirasanagandla S, Nannepaga S, Piccirillo SG, Kovacs Z, Foong C, et al. 2014. Acetate is a bioenergetic substrate for human glioblastoma and brain metastases. Cell 159: 1603-1614. doi:10.1016/j.cell.2014.11.025

McBrayer SK, Mayers JR, DiNatale GJ, Shi DD, Khanal J, Chakraborty AA, Sarosiek KA, Briggs KJ, Robbins AK, Sewastianik T, et al. 2018. Transaminase inhibition by 2-hydroxyglutarate impairs glutamate biosynthesis and redox homeostasis in glioma. Cell 175: 101-116.e25. doi:10.1016/j.cell.2018.08.038

Miller TE, Liau BB, Wallace LC, Morton AR, Xie Q, Dixit D, Factor DC, Kim LJY, Morrow JJ, Wu Q, et al. 2017. Transcription elongation factors represent in vivo cancer dependencies in glioblastoma. Nature 547: 355-359. doi:10.1038/nature23000

Miroshnikova YA, Mouw JK, Barnes JM, Pickup MW, Lakins JN, Kim Y, Lobo K, Persson AI, Reis GF, McKnight TR, et al. 2016. Tissue mechanics promote IDH1-dependent HIFla-tenascin C feedback to regulate glioblastoma aggression. Nat Cell Biol 18: 1336-1345. doi:10.1038/ncb3429

Mitchell DA, Batich KA, Gunn MD, Huang MN, Sanchez-Perez L, Nair SK, Congdon KL, Reap EA, Archer GE, Desjardins A, et al. 2015. Tetanus toxoid and CCL3 improve dendritic cell vaccines in mice and glioblastoma patients. Nature 519: 366-369. doi:10.1038/nature 14320

Miyai M, Tomita H, Soeda A, Yano H, Iwama T, Hara A. 2017. Current trends in mouse models of glioblastoma. J Neurooncol 135: 423-432. doi:10.1007/s11060-017-2626-2

Nagaraja S, Vitanza NA, Woo PJ, Taylor KR, Liu F, Zhang L, Li M, Meng W, Ponnuswami A, Sun W, et al. 2017. Transcriptional dependencies in diffuse intrinsic pontine glioma. Cancer Cell 31: 635-652.e6. doi:10.1016/j.ccell.2017.03.011

O'Brien CA, Pollett A, Gallinger S, Dick JE. 2007. A human colon cancer cell capable of initiating tumour growth in immunodeficient mice. Nature 445: 106-110. doi:10.1038/nature05372

Ogawa J, Pao GM, Shokhirev MN, Verma IM. 2018. Glioblastoma model using human cerebral organoids. Cell Rep 23: 12201229. doi:10.1016/j.celrep.2018.03.105 
Oldrini B, Curiel-Garcia Á, Marques C, Matia V, Uluçkan Ö, Graña-Castro O, Torres-Ruiz R, Rodriguez-Perales S, Huse JT, Squatrito M. 2018. Somatic genome editing with the RCASTVA-CRISPR-Cas9 system for precision tumor modeling. Nat Commun 9: 1466. doi:10.1038/s41467-018-03731-w

O'Rourke DM, Nasrallah MP, Desai A, Melenhorst JJ, Mansfield K, Morrissette JJD, Martinez-Lage M, Brem S, Maloney E, Shen A, et al. 2017. A single dose of peripherally infused EGFRvIII-directed CAR T cells mediates antigen loss and induces adaptive resistance in patients with recurrent glioblastoma. Sci Trans1 Med 9: eaaa0984. doi:10.1126/scitranslmed .aaa0984

Osswald M, Jung E, Sahm F, Solecki G, Venkataramani V, Blaes I, Weil S, Horstmann H, Wiestler B, Syed M, et al. 2015. Brain tumour cells interconnect to a functional and resistant network. Nature 528: 93-98. doi:10.1038/nature16071

Ostrom QT, Gittleman H, Fulop J, Liu M, Blanda R, Kromer C, Wolinsky Y, Kruchko C, Barnholtz-Sloan JS. 2015. CBTRUS statistical report: primary brain and central nervous system tumors diagnosed in the United States in 2008-2012. Neuro Oncol 17: iv1-iv62. doi:10.1093/neuonc/nov189

Otvos B, Silver DJ, Mulkearns-Hubert EE, Alvarado AG, Turaga SM, Sorensen MD, Rayman P, Flavahan WA, Hale JS, Stoltz $\mathrm{K}$, et al. 2016. Cancer stem cell-secreted macrophage migration inhibitory factor stimulates myeloid derived suppressor cell function and facilitates glioblastoma immune evasion. Stem Cells 34: 2026-2039. doi:10.1002/stem.2393

Palanichamy K, Kanji S, Gordon N, Thirumoorthy K, Jacob JR, Litzenberg KT, Patel D, Chakravarti A. 2017. NNMT silencing activates tumor suppressor PP2A, inactivates oncogenic STKs, and inhibits tumor forming ability. Clin Cancer Res 23: 2325-2334. doi:10.1158/1078-0432.CCR-16-1323

Park NI, Guilhamon P, Desai K, McAdam RF, Langille E, O'Connor M, Lan X, Whetstone H, Coutinho FJ, Vanner RJ, et al. 2017. ASCL1 reorganizes chromatin to direct neuronal fate and suppress tumorigenicity of glioblastoma stem cells. Cell Stem Cell 21: 209-224.e7. doi:10.1016/j.stem.2017.06.004

Pastrana E, Silva-Vargas V, Doetsch F. 2011. Eyes wide open: a critical review of sphere-formation as an assay for stem cells. Cell Stem Cell 8: 486-498. doi:10.1016/j.stem.2011.04.007

Patel AP, Tirosh I, Trombetta JJ, Shalek AK, Gillespie SM, Wakimoto H, Cahill DP, Nahed BV, Curry WT, Martuza RL, et al. 2014. Single-cell RNA-seq highlights intratumoral heterogeneity in primary glioblastoma. Science 344: 1396-1401. doi:10.1126/science.1254257

Pavlova NN, Thompson CB. 2016. The emerging hallmarks of cancer metabolism. Cell Metab 23: 27-47. doi:10.1016/j .cmet.2015.12.006

Pavlyukov MS, Yu H, Bastola S, Minata M, Shender VO, Lee Y, Zhang S, Wang J, Komarova S, Wang J, et al. 2018. Apoptotic cell-derived extracellular vesicles promote malignancy of glioblastoma via intercellular transfer of splicing factors. Cancer Cell 34: 119-135.e10. doi:10.1016/j.ccell.2018.05.012

Pietras A, Katz AM, Ekström EJ, Wee B, Halliday JJ, Pitter KL, Werbeck JL, Amankulor NM, Huse JT, Holland EC. 2014. Osteopontin-CD44 signaling in the glioma perivascular niche enhances cancer stem cell phenotypes and promotes aggressive tumor growth. Cell Stem Cell 14: 357-369. doi:10.1016/ j.stem.2014.01.005

Piwecka M, Rolle K, Belter A, Barciszewska AM, Żywicki M, Michalak M, Nowak S, Naskrẹt-Barciszewska MZ, Barciszewski J. 2015. Comprehensive analysis of microRNA expression profile in malignant glioma tissues. Mol Oncol 9: 13241340. doi:10.1016/j.molonc.2015.03.007
Pollard SM, Yoshikawa K, Clarke ID, Danovi D, Stricker S, Russell R, Bayani J, Head R, Lee M, Bernstein M, et al. 2009. Glioma stem cell lines expanded in adherent culture have tumor-specific phenotypes and are suitable for chemical and genetic screens. Cell Stem Cell 4: 568-580. doi:10.1016/j.stem .2009.03.014

Pollen AA, Nowakowski TJ, Chen J, Retallack H, Sandoval-Espinosa C, Nicholas CR, Shuga J, Liu SJ, Oldham MC, Diaz A, et al. 2015. Molecular identity of human outer radial glia during cortical development. Cell 163: 55-67. doi:10.1016/j.cell 2015.09.004

Portnow J, Synold TW, Badie B, Tirughana R, Lacey SF, D'Apuzzo M, Metz MZ, Najbauer J, Bedell V, Vo T, et al. 2017. Neural stem cell-based anticancer gene therapy: a first-in-human study in recurrent high-grade glioma patients. Clin Cancer Res 23: 2951-2960. doi:10.1158/1078-0432.CCR-16-1518

Prins RM, Soto H, Konkankit V, Odesa SK, Eskin A, Yong WH, Nelson SF, Liau LM. 2011. Gene expression profile correlates with T-cell infiltration and relative survival in glioblastoma patients vaccinated with dendritic cell immunotherapy. Clin Cancer Res 17: 1603-1615. doi:10.1158/1078-0432 .CCR-10-2563

Prosniak M, Harshyne LA, Andrews DW, Kenyon LC, Bedelbaeva K, Apanasovich TV, Heber-Katz E, Curtis MT, Cotzia P, Hooper DC. 2013. Glioma grade is associated with the accumulation and activity of cells bearing M2 monocyte markers. Clin Cancer Res 19: 3776-3786. doi:10.1158/1078-0432 .CCR-12-1940

Puchalski RB, Shah N, Miller J, Dalley R, Nomura SR, Yoon JG, Smith KA, Lankerovich M, Bertagnolli D, Bickley K, et al. 2018. An anatomic transcriptional atlas of human glioblastoma. Science 360: 660-663. doi:10.1126/science.aaf2666

Pyonteck SM, Akkari L, Schuhmacher AJ, Bowman RL, Sevenich L, Quail DF, Olson OC, Quick ML, Huse JT, Teijeiro V, et al. 2013. CSF-1R inhibition alters macrophage polarization and blocks glioma progression. Nat Med 19: 1264-1272. doi:10 $.1038 / \mathrm{nm} .3337$

Qin EY, Cooper DD, Abbott KL, Lennon J, Nagaraja S, Mackay A, Jones C, Vogel H, Jackson PK, Monje M. 2017. Neural precursor-derived pleiotrophin mediates subventricular zone invasion by glioma. Cell 170: 845-859.e19. doi:10.1016/j.cell 2017.07.016

Quail DF, Bowman RL, Akkari L, Quick ML, Schuhmacher AJ, Huse JT, Holland EC, Sutton JC, Joyce JA. 2016. The tumor microenvironment underlies acquired resistance to CSF-1R inhibition in gliomas. Science 352: aad3018. doi:10.1126/sci ence.aad3018

Ricci-Vitiani L, Lombardi DG, Pilozzi E, Biffoni M, Todaro M, Peschle C, De Maria R. 2007. Identification and expansion of human colon-cancer-initiating cells. Nature 445: 111-115. doi:10.1038/nature05384

Ricklefs FL, Alayo Q, Krenzlin H, Mahmoud AB, Speranza MC, Nakashima H, Hayes JL, Lee K, Balaj L, Passaro C, et al. 2018. Immune evasion mediated by PD-L1 on glioblastomaderived extracellular vesicles. Sci $A d v$ 4: eaar2766. doi:10 $.1126 /$ sciadv.aar2766

Saha D, Martuza RL, Rabkin SD. 2017. Macrophage polarization contributes to glioblastoma eradication by combination immunovirotherapy and immune checkpoint blockade. Cancer Cell 32: 253-267.e5. doi:10.1016/j.ccell.2017.07.006

Sana J, Busek P, Fadrus P, Besse A, Radova L, Vecera M, Reguli S, Stollinova Sromova L, Hilser M, Lipina R, et al. 2018. Identification of microRNAs differentially expressed in glioblastoma stem-like cells and their association with patient survival. Sci Rep 8: 2836. doi:10.1038/s41598-018-20929-6 
Sarkar S, Mirzaei R, Zemp FJ, Wei W, Senger DL, Robbins SM, Yong VW. 2017. Activation of NOTCH signaling by tenascin-C promotes growth of human brain tumor-initiating cells. Cancer Res 77: 3231-3243. doi:10.1158/0008-5472.CAN-162171

Schonberg DL, Miller TE, Wu Q, Flavahan WA, Das NK, Hale JS, Hubert CG, Mack SC, Jarrar AM, Karl RT, et al. 2015. Preferential iron trafficking characterizes glioblastoma stem-like cells. Cancer Cell 28: 441-455. doi:10.1016/j.ccell.2015.09 .002

Shi Y, Ping YF, Zhou W, He ZC, Chen C, Bian BS, Zhang L, Chen L, Lan X, Zhang XC, et al. 2017. Tumour-associated macrophages secrete pleiotrophin to promote PTPRZ1 signalling in glioblastoma stem cells for tumour growth. Nat Commun 8: 15080. doi:10.1038/ncomms 15080

Shi Y, Guryanova OA, Zhou W, Liu C, Huang Z, Fang X, Wang X, Chen C, Wu Q, He Z, et al. 2018. Ibrutinib inactivates BMXSTAT3 in glioma stem cells to impair malignant growth and radioresistance. Sci Transl Med 10: eaah6816. doi:10.1126/sci translmed.aah6816

Shingu T, Ho AL, Yuan L, Zhou X, Dai C, Zheng S, Wang Q, Zhong Y, Chang Q, Horner JW, et al. 2017. Qki deficiency maintains stemness of glioma stem cells in suboptimal environment by downregulating endolysosomal degradation. Nat Genet 49: 75-86. doi:10.1038/ng.3711

Singh SK, Clarke ID, Terasaki M, Bonn VE, Hawkins C, Squire J, Dirks PB. 2003. Identification of a cancer stem cell in human brain tumors. Cancer Res 63: 5821-5828.

Singh SK, Hawkins C, Clarke ID, Squire JA, Bayani J, Hide T, Henkelman RM, Cusimano MD, Dirks PB. 2004. Identification of human brain tumour initiating cells. Nature 432: 396-401. doi:10.1038/nature03128

Singh DK, Kollipara RK, Vemireddy V, Yang XL, Sun Y, Regmi N, Klingler S, Hatanpaa KJ, Raisanen J, Cho SK, et al. 2017. Oncogenes activate an autonomous transcriptional regulatory circuit that drives glioblastoma. Cell Rep 18: 961-976. doi:10 $.1016 /$ j.celrep.2016.12.064

Son MJ, Woolard K, Nam DH, Lee J, Fine HA. 2009. SSEA-1 is an enrichment marker for tumor-initiating cells in human glioblastoma. Cell Stem Cell 4: 440-452. doi:10.1016/j.stem .2009 .03 .003

Staberg M, Rasmussen RD, Michaelsen SR, Pedersen H, Jensen KE, Villingshøj M, Skjoth-Rasmussen J, Brennum J, VittingSeerup K, Poulsen HS, et al. 2018. Targeting glioma stemlike cell survival and chemoresistance through inhibition of lysine-specific histone demethylase KDM2B. Mol Oncol 12: 406-420. doi:10.1002/1878-0261.12174

Stupp R, Mason WP, van den Bent MJ, Weller M, Fisher B, Taphoorn MJ, Belanger K, Brandes AA, Marosi C, Bogdahn $\mathrm{U}$, et al. 2005. Radiotherapy plus concomitant and adjuvant temozolomide for glioblastoma. N Engl J Med 352: 987-996. doi:10.1056/NEJMoa043330

Stupp R, Hegi ME, Mason WP, van den Bent MJ, Taphoorn MJ, Janzer RC, Ludwin SK, Allgeier A, Fisher B, Belanger K, et al. 2009. Effects of radiotherapy with concomitant and adjuvant temozolomide versus radiotherapy alone on survival in glioblastoma in a randomised phase III study: 5-year analysis of the EORTC-NCIC trial. Lancet Oncol 10: 459-466. doi:10 .1016/S1470-2045/09)70025-7

Stupp R, Taillibert S, Kanner A, Read W, Steinberg D, Lhermitte B, Toms S, Idbaih A, Ahluwalia MS, Fink K, et al. 2017. Effect of tumor-treating fields plus maintenance temozolomide vs maintenance temozolomide alone on survival in patients with glioblastoma: a randomized clinical trial. JAMA 318: 2306-2316. doi:10.1001/jama.2017.18718
Sulli G, Rommel A, Wang X, Kolar MJ, Puca F, Saghatelian A, Plikus MV, Verma IM, Panda S. 2018. Pharmacological activation of REV-ERBs is lethal in cancer and oncogene-induced senescence. Nature 553: 351-355. doi:10.1038/nature25170

Sun L, Yan W, Wang Y, Sun G, Luo H, Zhang J, Wang X, You Y, Yang Z, Liu N. 2011. MicroRNA-10b induces glioma cell invasion by modulating MMP-14 and UPAR expression via HOXD10. Brain Res 1389: 9-18. doi:10.1016/j.brainres.2011 .03 .013

Tardito S, Oudin A, Ahmed SU, Fack F, Keunen O, Zheng L, Miletic H, Sakariassen PØ, Weinstock A, Wagner A, et al. 2015. Glutamine synthetase activity fuels nucleotide biosynthesis and supports growth of glutamine-restricted glioblastoma. Nat Cell Biol 17: 1556-1568. doi:10.1038/ncb3272

Teplyuk NM, Uhlmann EJ, Gabriely G, Volfovsky N, Wang Y, Teng J, Karmali P, Marcusson E, Peter M, Mohan A, et al. 2016. Therapeutic potential of targeting microRNA-10b in established intracranial glioblastoma: first steps toward the clinic. EMBO Mol Med 8: 268-287. doi:10.15252/emmm .201505495

Tirosh I, Venteicher AS, Hebert C, Escalante LE, Patel AP, Yizhak K, Fisher JM, Rodman C, Mount C, Filbin MG, et al. 2016. Single-cell RNA-seq supports a developmental hierarchy in human oligodendroglioma. Nature 539: 309-313. doi:10.1038/ nature 20123

Turcan S, Rohle D, Goenka A, Walsh LA, Fang F, Yilmaz E, Campos C, Fabius AW, Lu C, Ward PS, et al. 2012. IDH1 mutation is sufficient to establish the glioma hypermethylator phenotype. Nature 483: 479-483. doi:10.1038/nature10866

Turcan S, Makarov V, Taranda J, Wang Y, Fabius AWM, Wu W, Zheng Y, El-Amine N, Haddock S, Nanjangud G, et al. 2018. Mutant-IDH1-dependent chromatin state reprogramming, reversibility, and persistence. Nat Genet 50: 62-72. doi:10.1038/ s41588-017-0001-z

Ulanovskaya OA, Zuhl AM, Cravatt BF. 2013. NNMT promotes epigenetic remodeling in cancer by creating a metabolic methylation sink. Nat Chem Biol 9: 300-306. doi:10.1038/nchem bio. 1204

van den Bossche WBL, Kleijn A, Teunissen CE, Voerman JSA, Teodosio C, Noske DP, van Dongen JJM, Dirven CMF, Lamfers MLM. 2018. Oncolytic virotherapy in glioblastoma patients induces a tumor macrophage phenotypic shift leading to an altered glioblastoma microenvironment. Neuro Oncol 20: 1494-1504. doi:10.1093/neuonc/noy082

Venkatesh HS, Johung TB, Caretti V, Noll A, Tang Y, Nagaraja S, Gibson EM, Mount CW, Polepalli J, Mitra SS, et al. 2015. Neuronal activity promotes glioma growth through neuroligin-3 secretion. Cell 161: 803-816. doi:10.1016/j.cell.2015.04.012

Venkatesh HS, Tam LT, Woo PJ, Lennon J, Nagaraja S, Gillespie SM, Ni J, Duveau DY, Morris PJ, Zhao JJ, et al. 2017. Targeting neuronal activity-regulated neuroligin-3 dependency in highgrade glioma. Nature 549: 533-537. doi:10.1038/nature24014

Venteicher AS, Tirosh I, Hebert C, Yizhak K, Neftel C, Filbin MG, Hovestadt V, Escalante LE, Shaw ML, Rodman C, et al. 2017. Decoupling genetics, lineages, and microenvironment in IDH-mutant gliomas by single-cell RNA-seq. Science 355: eaai8478. doi:10.1126/science.aai8478

Villa GR, Hulce JJ, Zanca C, Bi J, Ikegami S, Cahill GL, Gu Y, Lum KM, Masui K, Yang H, et al. 2016. An LXR-cholesterol axis creates a metabolic co-dependency for brain cancers. Cancer Cell 30: 683-693. doi:10.1016/j.ccell.2016.09.008

Vinagre J, Almeida A, Pópulo H, Batista R, Lyra J, Pinto V, Coelho R, Celestino R, Prazeres H, Lima L, et al. 2013. Frequency of TERT promoter mutations in human cancers. Nat Commun 4: 2185 . doi:10.1038/ncomms 3185 
Visvanathan A, Patil V, Arora A, Hegde AS, Arivazhagan A, Santosh V, Somasundaram K. 2018. Essential role of METTL3mediated $\mathrm{m}^{6} \mathrm{~A}$ modification in glioma stem-like cells maintenance and radioresistance. Oncogene 37: 522-533. doi:10.1038/onc.2017.351

Wakimoto H, Kesari S, Farrell CJ, Curry WT Jr, Zaupa C, Aghi M, Kuroda T, Stemmer-Rachamimov A, Shah K, Liu TC, et al. 2009. Human glioblastoma-derived cancer stem cells: establishment of invasive glioma models and treatment with oncolytic herpes simplex virus vectors. Cancer Res 69: 3472-3481. doi:10.1158/0008-5472.CAN-08-3886

Wan F, Zhang S, Xie R, Gao B, Campos B, Herold-Mende C, Lei T. 2010. The utility and limitations of neurosphere assay, CD133 immunophenotyping and side population assay in glioma stem cell research. Brain Pathol 20: 877-889. doi:10.1111/j .1750-3639.2010.00379.x

Wang Q, Hu B, Hu X, Kim H, Squatrito M, Scarpace L, deCarvalho AC, Lyu S, Li P, Li Y, et al. 2017a. Tumor evolution of gliomaintrinsic gene expression subtypes associates with immunological changes in the microenvironment. Cancer Cell 32: 42-56.e6. doi:10.1016/j.ccell.2017.06.003

Wang X, Huang Z, Wu Q, Prager BC, Mack SC, Yang K, Kim LJY, Gimple RC, Shi Y, Lai S, et al. 2017b. MYC-regulated mevalonate metabolism maintains brain tumor initiating cells. Cancer Res 77: 4947-4960. doi:10.1158/0008-5472.CAN-17-0114

Wang X, Yang K, Xie Q, Wu Q, Mack SC, Shi Y, Kim LJY, Prager BC, Flavahan WA, Liu X, et al. 2017c. Purine synthesis promotes maintenance of brain tumor initiating cells in glioma. Nat Neurosci 20: 661-673. doi:10.1038/nn.4537

Wang X, Prager BC, Wu Q, Kim LJY, Gimple RC, Shi Y, Yang K, Morton AR, Zhou W, Zhu Z, et al. 2018. Reciprocal signaling between glioblastoma stem cells and differentiated tumor cells promotes malignant progression. Cell Stem Cell 22: 514-528.e5. doi:10.1016/j.stem.2018.03.011

Wang J, Xu SL, Duan JJ, Yi L, Guo YF, Shi Y, Li L, Yang ZY, Liao $\mathrm{XM}$, Cai J, et al. 2019. Invasion of white matter tracts by glioma stem cells is regulated by a NOTCH1-SOX2 positive-feedback loop. Nat Neurosci 22: 91-105. doi:10.1038/s41593-0180285-z

Xie Q, Wu Q, Kim L, Miller TE, Liau BB, Mack SC, Yang K, Factor DC, Fang X, Huang Z, et al. 2016. RBPJ maintains brain tumor-initiating cells through CDK9-mediated transcriptional elongation. I Clin Invest 126: 2757-2772. doi:10.1172/ JCI86114

Xie Q, Wu TP, Gimple RC, Li Z, Prager BC, Wu Q, Yu Y, Wang P, Wang Y, Gorkin DU, et al. 2018. $\mathrm{N}^{6}$-methyladenine DNA modification in glioblastoma. Cell 175: 1228-1243.e20. doi:10.1016/j.cell.2018.10.006

Xiong Z, Wang L, Wang Q, Yuan Y. 2018. LncRNA MALAT1/ miR-129 axis promotes glioma tumorigenesis by targeting SOX2. J Cell Mol Med doi:10.1111/jcmm.13667

Yasumoto Y, Miyazaki H, Vaidyan LK, Kagawa Y, Ebrahimi M, Yamamoto Y, Ogata M, Katsuyama Y, Sadahiro H, Suzuki M, et al. 2016. Inhibition of fatty acid synthase decreases expression of stemness markers in glioma stem cells. PLoS One 11: e0147717. doi:10.1371/journal.pone.0147717

Zhang S, Zhao BS, Zhou A, Lin K, Zheng S, Lu Z, Chen Y, Sulman EP, Xie K, Bögler O, et al. 2017. m A demethylase ALKBH5 maintains tumorigenicity of glioblastoma stem-like cells by sustaining FOXM1 expression and cell proliferation program. Cancer Cell 31: 591-606.e6. doi:10.1016/j.ccell.2017.02.013

Zhang Y, Yu G, Chu H, Wang X, Xiong L, Cai G, Liu R, Gao H, Tao B, Li W, et al. 2018. Macrophage-associated PGK1 phosphorylation promotes aerobic glycolysis and tumorigenesis. Mol Cell 71: 201-215.e7. doi:10.1016/j.molcel.2018.06.023

Zhao H, Shen J, Hodges TR, Song R, Fuller GN, Heimberger AB. 2017. Serum microRNA profiling in patients with glioblastoma: a survival analysis. Mol Cancer 16: 59. doi:10.1186/ s12943-017-0628-5

Zhou W, Ke SQ, Huang Z, Flavahan W, Fang X, Paul J, Wu L, Sloan AE, McLendon RE, Li X, et al. 2015. Periostin secreted by glioblastoma stem cells recruits M2 tumour-associated macrophages and promotes malignant growth. Nat Cell Biol 17: 170-182. doi:10.1038/ncb3090

Zhou W, Chen C, Shi Y, Wu Q, Gimple RC, Fang X, Huang Z, Zhai K, Ke SQ, Ping YF, et al. 2017. Targeting glioma stem cell-derived pericytes disrupts the blood-tumor barrier and improves chemotherapeutic efficacy. Cell Stem Cell 21: 591-603.e4. doi:10.1016/j.stem.2017.10.002

Zhou D, Alver BM, Li S, Hlady RA, Thompson JJ, Schroeder MA, Lee JH, Qiu J, Schwartz PH, Sarkaria JN, et al. 2018. Distinctive epigenomes characterize glioma stem cells and their response to differentiation cues. Genome Biol 19: 43. doi:10 .1186/s13059-018-1420-6

Zhu Y, Guignard F, Zhao D, Liu L, Burns DK, Mason RP, Messing A, Parada LF. 2005. Early inactivation of p53 tumor suppressor gene cooperating with NF1 loss induces malignant astrocytoma. Cancer Cell 8: 119-130. doi:10.1016/j.ccr.2005.07.004

Zhu Z, Gorman MJ, McKenzie LD, Chai JN, Hubert CG, Prager BC, Fernandez E, Richner JM, Zhang R, Shan C, et al. 2017. Zika virus has oncolytic activity against glioblastoma stem cells. J Exp Med 214: 2843-2857. doi:10.1084/jem.20171093 


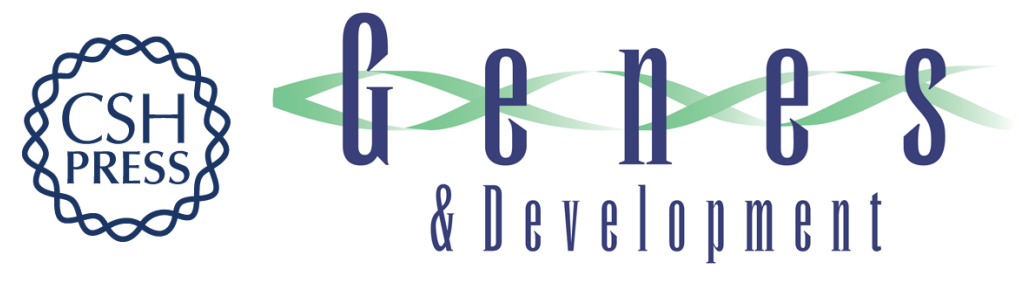

\section{Glioblastoma stem cells: lessons from the tumor hierarchy in a lethal cancer}

Ryan C. Gimple, Shruti Bhargava, Deobrat Dixit, et al.

Genes Dev. 2019, 33:

Access the most recent version at doi:10.1101/gad.324301.119

\begin{tabular}{|c|c|}
\hline References & $\begin{array}{l}\text { This article cites } 187 \text { articles, } 42 \text { of which can be accessed free at: } \\
\text { http://genesdev.cshlp.org/content/33/11-12/591.full.html\#ref-list-1 }\end{array}$ \\
\hline $\begin{array}{r}\text { Creative } \\
\text { Commons } \\
\text { License }\end{array}$ & $\begin{array}{l}\text { This article is distributed exclusively by Cold Spring Harbor Laboratory Press for the first } \\
\text { six months after the full-issue publication date (see } \\
\text { http://genesdev.cshlp.org/site/misc/terms.xhtml). After six months, it is available under a } \\
\text { Creative Commons License (Attribution-NonCommercial } 4.0 \text { International), as described } \\
\text { at http://creativecommons.org/licenses/by-nc/4.0/. }\end{array}$ \\
\hline $\begin{array}{l}\text { Email Alerting } \\
\text { Service }\end{array}$ & $\begin{array}{l}\text { Receive free email alerts when new articles cite this article - sign up in the box at the top } \\
\text { right corner of the article or click here. }\end{array}$ \\
\hline
\end{tabular}

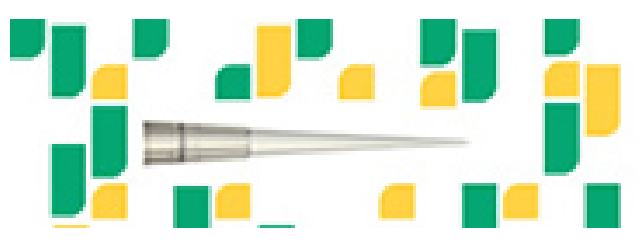

Focused on your science. 